\title{
Dollar Funding and the Lending Behavior of Global Banks
}

\section{Citation}

Ivashina, Victoria, David S. Scharfstein, and Jeremy C. Stein. "Dollar Funding and the Lending Behavior of Global Banks." Quarterly Journal of Economics (forthcoming).

\section{Permanent link}

http://nrs.harvard.edu/urn-3:HUL.InstRepos:15787970

\section{Terms of Use}

This article was downloaded from Harvard University's DASH repository, and is made available under the terms and conditions applicable to Open Access Policy Articles, as set forth at http:// nrs.harvard.edu/urn-3:HUL.InstRepos:dash.current.terms-of-use\#OAP

\section{Share Your Story}

The Harvard community has made this article openly available.

Please share how this access benefits you. Submit a story.

\section{Accessibility}




\title{
DOLLAR FUNDING AND THE LENDING BEHAVIOR OF GLOBAL BANKS
}

\author{
VICTORIA IVASHINA \\ DAVID S. SCHARFSTEIN \\ JEREMY C. STEIN
}

First draft: October 2012

This draft: March 2015

\begin{abstract}
A large share of dollar-denominated lending is done by non-U.S. banks, particularly European banks. We present a model in which such banks cut dollar lending more than euro lending in response to a shock to their credit quality. Because these banks rely on wholesale dollar funding, while raising more of their euro funding through insured retail deposits, the shock leads to a greater withdrawal of dollar funding. Banks can borrow in euros and swap into dollars to make up for the dollar shortfall, but this may lead to violations of covered interest parity (CIP) when there is limited capital to take the other side of the swap trade. In this case, synthetic dollar borrowing also becomes expensive, which causes cuts in dollar lending. We test the model in the context of the Eurozone sovereign crisis, which escalated in the second half of 2011 and resulted in U.S. money-market funds sharply reducing their exposure to European banks in the year that followed. During this period dollar lending by Eurozone banks fell relative to their euro lending, and firms who were more reliant on Eurozone banks before the Eurozone crisis had a more difficult time borrowing.
\end{abstract}

JEL Codes: E44, F36, G01.

\footnotetext{
*We are grateful for helpful comments from Stephen Blyth, Martin Oehmke, Michael Palumbo, and from seminar participants at the $4^{\text {th }}$ Paris Spring Corporate Finance Conference, the Banque de France/OSEO Conference, Columbia Business School, the European Finance Association Annual Meeting, the Federal Reserve Bank of Chicago Conference on Bank Structure and Competition, the NBER Corporate Finance Meeting, Northwestern University (Kellogg), Stockholm School of Economics and World Bank. We thank Peter Crane from Crane Data LLC for sharing money-market-fund data with us, Toomas Laarits and Chris Allen for research assistance, and the Division of Research at Harvard Business School for research support.

Corresponding author: Victoria Ivashina, Harvard Business School, Baker Library 233, Boston, MA 02163, USA; e-mail vivashina@hbs.edu
} 


\section{INTRODUCTION}

A striking fact about international financial markets is that a large share of dollardenominated intermediation is performed by non-U.S. banks. This point is illustrated in Figure I. Drawing on data from the Bank for International Settlements (BIS), the figure shows that both the dollar assets and the dollar liabilities of foreign banking entities have grown rapidly in the last two decades, and currently are on the order of $\$ 10$ trillion, which puts them roughly on a par with U.S. banks (see also Shin, 2012). A significant part of this activity by foreign banks represents loans to customers located outside of the United States. However, foreign banks also play a major role in domestic U.S. markets. As we discuss in more detail below, European banks alone accounted for approximately $28 \%$ of the U.S. syndicated loan market over the period 20052007.

\section{[FIGURE I]}

The large footprint of global banks in dollar markets raises a number of questions. Some of these have to do with the dollar's role as a favored currency for transactions by non-U.S. residents and firms-e.g., why is it that a Brazilian manufacturer might prefer to borrow in dollars as opposed to reals? Others have to do with understanding the comparative advantage of foreign banks in lending to U.S. firms-e.g., why might an American manufacturer end up borrowing from, say, Credit Agricole as opposed to JPMorgan Chase?

In this paper, we take the presence of global banks in dollar loan markets as given, and focus on its consequences for cyclical variation in credit supply across countries. In particular, we ask how shocks to the ability of a foreign bank to raise dollar funding affect its lending behavior, both in the U.S., and in its home market. This question is especially important in light of the observation that many foreign banks operate in the U.S. with a largely "wholesale" 
funding model. In other words, rather than relying in part on sticky insured deposits-as do domestic U.S. banks—-foreign banks raise the majority of their short-term dollar financing from uninsured institutional sources, such as commercial paper purchased by U.S. money-market funds. ${ }^{1}$ This makes the cost and availability of such dollar funding highly sensitive to changing perceptions of a bank's creditworthiness.

To understand how such shocks might affect lending activity, we build a simple model, which can be described as follows. Imagine a global bank based in France that lends in euros to European firms, and in dollars to American firms. To finance the euro-denominated lending, it funds itself by issuing insured euro deposits to its local retail deposit base. By contrast, to finance the dollar-denominated lending, it funds itself by issuing uninsured commercial paper to a set of U.S. money-market funds. Initially, the bank is viewed as having near-zero credit risk, so its lack of insurance in the U.S. market does not have an impact on its dollar funding costs.

Now suppose that there is an adverse shock to the bank's perceived creditworthiness. Given the wholesale nature of its dollar liabilities (i.e., the lack of insurance), this leads to a spike in its dollar funding costs, as the money-market funds seek to cut their exposure to the bank. At the same time, the cost to the bank of funding in euros is unchanged, given the deposit insurance in that market. Said differently, as the bank becomes increasingly risky, the advantage of funding in euros relative to dollars goes up, since the former enjoys an increasingly valuable subsidy from the deposit insurance fund.

So we might expect the bank to shift its funding away from the U.S. commercial paper market and back towards the European deposit market. But does this have any implications for the geographic distribution of its lending? At first glance, one might think that there would be

1. When, as is often the case, foreign banks operate in the U.S. via a branch-as opposed to a separately capitalized subsidiary-they are legally precluded from raising FDIC-insured deposits. 
none-i.e., a version of a capital-structure irrelevance proposition would hold. After all, if it wants to maintain the volume of its dollar-based U.S. lending, the bank can always tap its insured deposit base to raise more euros, use the proceeds to buy dollars, make the same dollar loans as before, and hedge out the foreign exchange (FX) risk using the forward market, by buying euros on a forward basis. ${ }^{2}$

This logic is correct, so long as FX forward prices are pinned down by the usual coveredinterest-parity (CIP) relationship. In this case, a shock of the sort described above alters the funding mix of the global bank, but leaves its lending behavior entirely unchanged. However, if the induced funding realignment is big enough, we demonstrate that it begins to put pressure on the CIP relationship. In other words, a large surge in the demand by the global bank for FX forwards, combined with limited capacity on the part of arbitrageurs, endogenously leads to a CIP violation such that synthetic dollar funding-composed of euro-based borrowing plus a currency swap—also becomes more expensive. Indeed, in an interior equilibrium with a high level of swap activity, synthetic dollar funding and direct dollar funding wind up being equally costly to the bank, and both more expensive than direct euro borrowing.

Once this is the case, implications for the geographic pattern of lending follow immediately. Given the increased cost of dollar funding, the bank is forced to cut back on its supply of dollar loans, but does not face the same pressure to shrink its euro-denominated loan supply. So the key conclusion from the model is that, in the presence of limited arbitrage and an endogenous CIP violation, an adverse shock to the global bank's perceived creditworthiness leads to a drop in its dollar-denominated lending relative to its euro-denominated lending.

2. We are implicitly assuming that the bank is prohibited from taking on naked exchange-rate exposure, i.e. from borrowing in euros, and lending in dollars without a hedge. We discuss this assumption in more detail below. 
We then go on to test the model's implications. To do so, we focus on events that unfolded from May 2011 to June 2012, a period that captures well the sort of shock to globalbank creditworthiness envisioned in our model. During this period, the credit quality of a number of large Eurozone banks began to be a source of concern, with Moody's putting the French banks BNP Paribas, Credit Agricole and Societe Generale on notice for possible downgrades on June 15, 2011. In the face of these concerns, U.S. prime money-market funds sharply reduced their investments in Eurozone banks. Chernenko and Sunderam (2014) document that the total money-fund holdings of Eurozone bank paper declined by 37\%, from \$453 billion to $\$ 287$ billion, between May and August of 2011. Fitch reports further declines through June 2012. ${ }^{3}$ Starting in the second half of 2012, the Eurozone situation began stabilize and money-fund holdings of Eurozone bank instruments started to rebound.

Coincident with the contraction in dollar funding, there was a pronounced disruption in the dollar-euro CIP relationship, in the direction predicted by our theory. The "euro basis"-i.e., the deviation in the forward price of euros in terms of dollars, and hence in the cost of synthetic dollar borrowing—rose from a negative 16 bps in April 2011, to a high of 73 bps in August, and continued to go up until reaching a peak of 96 bps in December 2011.

Using loan-level data on international syndicated lending activity from Thompson Reuters’ DealScan, we first show that during the period of dollar funding strain from May 2011 to June 2012, dollar lending by Eurozone banks fell relative to their euro lending, a pattern that differs sharply from that observed among U.S. banks. Next, as a control against possible confounding demand-side shocks, we construct a panel that allows us to incorporate borrower fixed effects. Using this approach, we find that during the period of dollar funding strain (the

3. "U.S. Money Fund Exposure and European Banks: Euro Zone Diverging,” Fitch Ratings, January 26, 2012. 
"shock" period), a syndicate formed to make a dollar-denominated loan to a given firm was less likely to be comprised of Eurozone banks than was a syndicate formed to make a loan to the same firm outside of the shock period. Thus our results cannot be explained by appealing to the idea that Eurozone and U.S. banks lend to different customers with different demand behavior.

This shift away from dollar lending by Eurozone banks could in principle have been offset by increased lending by U.S. banks, in which case the loan-supply shock would have had no real effects on corporate borrowers. However, we show that this type of substitution was at best incomplete: firms that before the 2011 shock had borrowed in dollars from syndicates comprised largely of Eurozone banks were less likely to receive any loans at all once these banks faced dollar funding problems. And those borrowers in this group that did receive loans paid higher interest rates. These findings provide support for the view that lending relationships are important in the syndicated loan market, and that when those relationships break down there can be real consequences—echoing recent work by Chodorow-Reich (2014).

Finally, in an effort to further isolate the mechanism in our model, we exploit the fact that Eurozone banks differ in the extent of their reliance on money-market funds. We document that, during the period of dollar funding strain, the tendency to cut back on dollar lending is more pronounced for the most money-fund-reliant Eurozone banks, as compared to their less moneyfund-reliant counterparts.

The bottom line of our analysis can be summarized as follows: Given limited arbitrage in FX forward markets, the wholesale dollar funding model typically employed by foreign bankswhereby they rely heavily on short-term uninsured sources of dollar finance-exposes their mix of lending activity to changes in perceived creditworthiness. In particular, adverse shocks to creditworthiness lead them to curtail their supply of dollar loans, relative to their supply of loans 
in their domestic currency. It is worth emphasizing that this is quite a different mechanism than the more familiar capital-crunch channel (as in Peek and Rosengren 1997, 2000), according to which a global bank hit with a negative shock to its capital base might be expected to cut back on lending across the board, regardless of the currency in which the lending takes place.

This paper fits into a large literature that studies how financing frictions shape bank lending behavior. A subset of this research focuses, as we do, on multinational banks and the role they play in transmitting various kinds of shocks across borders. In addition to the important early contributions by Peek and Rosengren (1997, 2000), recent research includes Acharya and Schnabl (2010), Chava and Purnanandam (2011), Schnabl (2012), and Cetorelli and Goldberg (2011, 2012a, 2012b). Our empirical results are closely related to those of Acharya, Afonso and Kovner (2013), and Correa, Sapriza and Zlate (2012). The former investigates the differential response of U.S. and foreign banks to the funding pressures created by the 2007 collapse of the asset-backed commercial paper market, and the latter focuses on the same 2011 European shock that we do.

Particularly noteworthy are a pair of recent papers by Giannetti and Laeven (2012a, 2012b). These papers document a generalized "flight home" effect, whereby in periods of financial stress, global banks tend to reduce their lending share abroad relative to their lending share in their home-country markets. Although we focus on the currency-rather than the country —in which global banks lend, the two effects are likely related, and the mechanism that we propose may help to explain this general phenomenon. We discuss this connection in more detail below.

There is also a smaller literature that analyzes the CIP violations that have cropped up intermittently since the onset of the financial crisis. These include Baba, Packer, and Nagano 
(2008), Coffey, Hrung, and Sarkar (2009), Griffoli and Ranaldo (2011), and Levich (2012). These papers discuss the frictions that prevent arbitrage from eliminating a CIP deviation once it emerges, but have less to say about what determines the direction and magnitude of the deviation in the first place. By contrast, in our model the CIP violation is an equilibrium outcome, and we show how it depends not only on the capital of arbitrageurs, but also on global banks' funding opportunities across dollar and non-dollar markets, and on the marginal product of their lending in each currency. That is, we connect CIP violations to the real side of the economy.

The remainder of the paper is organized as follows. Section II presents the model. Section III discusses our data sources and provides background information on the three critical components or our analysis: the role of Eurozone banks in syndicated lending in the U.S.; the dependence of Eurozone banks on dollar financing from U.S. money-market funds along with the decline in money fund assets in the second half of 2011; and the violation of covered interest parity during that same period. Section IV describes our main empirical tests, which examine the impact of the money-fund shock on loan supply by Eurozone banks. Section V concludes.

\section{MODEL}

\section{II.A. Basic Assumptions}

Our model considers a global bank $B$ that has lending opportunities in both the U.S. and Europe. If it lends an amount $L^{D}$ in dollars in the U.S. at time 0, it earns an expected gross return of $g\left(L^{D}\right)$ at time 1 , where $g($.$) is a concave function. Similarly, if the bank lends an$ amount $L^{E}$ in euros in Europe at time 0, it earns an expected gross return of $h\left(L^{E}\right)$ at time 1 , where again, $h($.$) is a concave function. To keep the notation simple, we assume that riskless$ 
rates in the U.S. and Europe are both equal to $r$, and that the spot dollar/euro exchange rate, $X^{S}$, is equal to one.

The bank faces an overall capital constraint on lending, such that aggregate lending is capped by: $L^{D}+L^{E} \leq K$. This constraint, which we assume binds in equilibrium, can be thought of as reflecting the combination of a regulatory capital regime, along with frictional costs to the bank of raising external equity finance (Myers and Majluf, 1984). We further assume that if the bank wishes to lend in dollars, it must effectively fund in dollars, and analogously for euro lending-i.e., it cannot take on any unhedged FX risk. We take this restriction as exogenous here, but it could easily be endogenized by appealing to the real-world fact that if a bank were to take on FX risk in this way, it would face an additional regulatory capital charge. ${ }^{4}$ If the shadow value of the regulatory capital constraint is high enough, it will be optimal for the bank to conserve its scarce capital by avoiding any FX exposure.

The bank has a probability $p$ of default. We assume that if the bank defaults, all of its loans in both the U.S. and Europe turn out to be worthless, and it has no resources to pay to any of its debts. Note therefore that if the bank earns an expected gross return of $g\left(L^{D}\right)$ on its dollar lending, it must be that the return accrues entirely in the non-default state. So it is more precise to say the bank earns a gross return of $g\left(L^{D}\right) /(1-p)$ with probability $(1-p)$, and zero otherwise. The same applies to its returns on euro lending.

If the bank borrows from European depositors and it defaults, these depositors are made whole by the government. Hence the rate that the bank pays on European borrowing $r_{E}^{B}$, is the riskless rate: $r_{E}^{B}=r$. Said differently, there is a government subsidy associated with European-

4. Under the current regulatory framework, increased exposure to FX risk is costly to the bank. This treatment of FX risk dates back to Basel I. In a study conducted in the context of the Basel I discussion, FX risk was identified as one the fundamental risks: "There are many activities of banks which involve risk-taking, but there are few in which a bank may so quickly incur large losses as in foreign exchange transactions.” (www.bis.org/publ/bcbs00e.htm.) 
sourced euro borrowing, and this subsidy is an increasing function of the default probability $p$. However, in order to attract incremental deposits the bank has to pay an adjustment cost that is convex in the amount of deposits above some threshold, $X>0$, so that borrowing $B^{E}$ euros costs $(1+r) B^{E}+\frac{\phi}{2} \max \left(0, B^{E}-X\right)^{2}$ where $\phi>0$. This assumption is meant to capture the idea that the bank cannot immediately expand its retail deposit base beyond some pre-existing baseline scale (given by $X$ ) at no cost. Rather, to expand it has to invest in advertising, promotions, and branches, and the more it expands in the short run the greater are the marginal costs of adding deposits.

While depositors in Europe are insured, if the bank borrows in the U.S. market, its creditors are only partially insured. Specifically, we assume that in expectation, U.S.-based lenders to the bank are only bailed out on a fraction $(1-\alpha)$ of their losses in the default state. As a result, the rate that the bank pays on U.S. borrowing, $r_{B}^{D}$, is approximated by: $r_{B}^{D}=r+\alpha p$. A literal interpretation of the parameter $\alpha$ is that it reflects the fraction of the bank's dollar financing that comes from, say, uninsured commercial paper, as opposed to deposits that are either explicitly insured, or that benefit from some perception of implicit insurance.

A less literal interpretation, but one that motivates our empirical work below, is that even among different providers of uninsured finance, some may be structurally "flightier" than others, and hence more sensitive to changes in bank creditworthiness. Money-market funds would seem to fit this description, given the run-like incentives created by their policy of allowing investors to redeem shares at a fixed value. We rely on this idea when we construct bank-level measures of $\alpha$, associating higher values of $\alpha$ with those banks that raise more of their short-term funding from money-market funds. 
Note that the funding costs in dollars, unlike euros, are linear in the amount borrowed. This assumption is meant to reflect the idea that dollar borrowing is mainly in the wholesale market via institutions like money market funds and thus can more easily be expanded in a short period of time than European retail deposits.

If $X$ is large enough such that the bank never hits the convex part of its euro borrowing, then it would want to raise all its funding in Europe and enter into an FX swap to cover the dollar-denominated portion of its lending. This is because the marginal cost of borrowing is just $(1+r)$ in Europe whereas it is $(1+r+\alpha p)$ in the U.S. For more moderate values of $X$ the bank would equate the marginal cost of borrowing across the two locations such that $\alpha p=$ $\phi\left(B^{E}-X\right)$. However, this assumes that the FX swap market is frictionless (i.e., CIP holds) an assumption we drop in the next section. But in this case of a frictionless swap market, the bank's funding and lending decisions decouple from one another. Funding is done in the mix of currencies that minimize funding costs, while lending activity in the two countries is pinned down by equating the marginal product of dollar lending to the marginal product of euro lending. And swap activity fills in the gap, by converting funding in one currency into the other as necessary.

\section{II.B. $\quad$ Limited Arbitrage and Deviations from CIP}

Frictions in the swap market can generate deviations from CIP and complicate the bank’s borrowing and lending decisions. As we demonstrate, these deviations arise when the bank's swap counterparties have limited capital, and are required to use this capital to post margin in their swap transactions. As a benchmark, note that with interest rates being equal in the two countries, and with the spot exchange rate normalized to one, a simplified version of the CIP relationship - which would always hold with capital-unconstrained parties on both sides of the 
trade—-is that the forward exchange rate must be equal to one as well. In other words, denoting the dollar/euro forward rate for a transaction in a frictionless world by $X_{S}^{F}$, we have that $X_{S}^{F}=1$.

Now consider the case where the counterparty is a capital-constrained arbitrageur. Let $X_{B}^{F}$ be the forward price paid by the bank in this case. To pin down this price, we make two further assumptions. First, the arbitrageur has to set aside a haircut $H$ when it enters the swap transaction; this can be thought of as the initial margin required as collateral for its position. ${ }^{5}$ To keep things simple, we follow Garleanu and Pedersen (2011) and assume that this haircut is proportional to the size $S$ of the swap position. So the haircut is given by $H=\gamma S$. Second, when the arbitrageur sets aside $H$ for swap trading, he has to take it away from another productive activity—e.g., lending, or another arbitrage trade. This other productive activity has a net return given by $f(I)$, where $I$ is the amount invested. The arbitrageur has wealth of $W$, so his budget constraint is that $I=W-H$, or $I=W-\gamma S$.

It follows that in an interior optimum where the arbitrageur is doing both activities, an equilibrium condition is that the expected excess return per unit earned on doing the swap, denoted $\Delta$, must satisfy: $\Delta=\gamma f^{\prime}(W-\gamma S)$. A convenient simple case is where $f(I)=\theta \log (I)-$ I, in which case we have that:

$$
\Delta=\gamma\left[\frac{\theta}{W-\gamma S}-1\right]
$$

5. We do not explicitly analyze the collateral posted by the bank, as opposed to by the arbitrageur. Instead, we just assume that the bank never defaults on its obligations under the swap contract, even if it does default on its short-term debt obligations. However, none of our main results are changed if there is a risk of default on the swap by the bank. This is because what matters for the bank in deciding how much swap activity to do is the premium it pays relative to the default-risk-adjusted actuarial value. Since this premium is a function of the arbitrageur's collateral constraint, and not the bank's, we focus on the former for the sake of clarity. 
To simplify even further, we assume $\Delta$ is zero when there is no net demand for swaps, but as soon as there is net demand for swaps $\Delta$ becomes positive. This amounts to saying that $\theta=W$, i.e., that the arbitrageur has just enough wealth $W$ to take advantage of all positive-NPV investment opportunities in his outside option project $f(I)$, with nothing left over. With this restriction, (1) reduces to $\Delta=\gamma^{2} S /(W-\gamma S)$.

The forward price paid by the bank is now given by:

$$
X_{B}^{F}=1+\Delta=1+\gamma^{2} S /(W-\gamma S)
$$

We can now see the fundamental tension facing the bank. As its creditworthiness declines-i.e., as $p$ goes up-it would like to increasingly fund its dollar lending with synthetic dollar borrowing, that is, by borrowing in euros and pairing this with an FX swap. However as the magnitude of its swap position $S$ grows, this puts increasing strain on the capital of the arbitrageurs who must take the other side of the trade, and hence creates a CIP deviation in which synthetic dollar borrowing becomes increasingly expensive-as reflected in the higher forward price that the bank must pay to buy back euros with dollars when its dollar loans mature at time 1 .

\section{II.C. The Bank’s Optimization Problem}

We are now ready to write down the bank's optimization problem. The bank's dollarbased lending is denoted by $L^{D}$, and the amount of euro borrowing that it swaps into dollars is denoted by $S$. This implies that its total dollar borrowing, $B^{D}$, is equal to $L^{D}-S$ and its euro borrowing, $B^{E}$, is $L^{E}+S$. The bank's optimization problem is to choose $\left\{L^{D}, L^{E}, S\right\}$ to maximize:

$g\left(L^{D}\right)-\left(L^{D}-S\right)(1+r+\alpha p)+h\left(L^{E}\right)-\left(L^{E}+S\right)(1+r)-\frac{\phi}{2} \max \left(0, L^{E}+S-X\right)^{2}-\Delta S$

subject to the capital constraint that $K-L^{D}-L^{E} \geq 0$. Here we are assuming that the parameters 
are such that the swap facilitates extra euro borrowing to fund dollar lending, not the other way around, i.e. $S \geq 0$. Below we will discuss the conditions under which this is the case.

Rearranging terms, the objective function (3) can be rewritten as follows:

$$
g\left(L^{D}\right)-L^{D}(1+r)+h\left(L^{E}\right)-L^{E}(1+r)-\alpha p L^{D}+(\alpha p-\Delta) S-\frac{\phi}{2} \max \left(0, L^{E}+S-X\right)^{2}
$$

The first four terms in $\left(3^{\prime}\right), g\left(L^{D}\right)-L^{D}(1+r)+h\left(L^{E}\right)-L^{E}(1+r)$, capture the net value created by the bank's lending in a frictionless world in which the marginal cost of funding in either currency is just $1+r$. The fifth term, $\alpha p L^{D}$, reflects the extra cost the bank incurs because of the default risk if it had to fund all of its dollar lending in U.S. money markets. The latter two terms embody the two key frictions in the model. The term $(\alpha p-\Delta) S$ is the net gain or loss from swapping extra euros raised overseas into dollars to fund dollar loans; while the bank saves $\alpha p S$ on dollar funding costs if it borrows in euros at cost $(1+r) S$, it pays $\Delta S$ to execute the swap. The last term, $\frac{\phi}{2} \max \left(0, L^{E}+S-X\right)^{2}$ reflects the fact that the incremental cost of euro deposit funding above $\mathrm{X}$ exceeds $1+r$ by an increasing amount.

The bank takes the frictional cost of the swap, $\Delta$, as given, even though in equilibrium $\Delta$ depends on $S$. That is, the bank is a price-taker in the swap market. This can be motivated by thinking of the bank that we are studying as a representative bank. In other words, one can imagine that there are many identical banks, of total measure one, just like the one whose optimization problem we have written down. Moreover, as we discuss below, the model is easily extended to the case where there is some heterogeneity across banks with respect to the parameter $\alpha$.

The first-order conditions for an interior maximum for $L^{D}, L^{E}$ and $S$ respectively can be written as:

$$
g^{\prime}\left(L^{D}\right)-(1+r)-\alpha p-\lambda=0
$$




$$
\begin{aligned}
& h^{\prime}\left(L^{E}\right)-(1+\mathrm{r})-\phi \max \left(0, L^{E}+S-X\right)-\lambda=0 . \\
& \alpha p-\Delta-\phi \max \left(0, L^{E}+S-X\right)=0 .
\end{aligned}
$$

Here $\lambda$ is the Lagrange multiplier on the capital constraint that $K-L^{D}-L^{E} \geq 0$, which we assume is binding.

Lending in both currencies will be strictly positive under the usual regularity assumptions on the $g$ and $h$ functions. Thus, (4) and (5) together imply that the bank equates the marginal benefits of lending in the two currencies net of funding costs:

$$
g^{\prime}\left(L^{D}\right)-\alpha p=h^{\prime}\left(L^{E}\right)-\phi \max \left(0, L^{E}+S-X\right)
$$

Equation (6), the first-order condition for an interior optimum in $S$, says that if the bank does any swaps at all, it sets the marginal cost of borrowing in dollars to the marginal cost of borrowing in euros and converting them into dollars. In an interior swap equilibrium, (6) can be used to rewrite (7) as:

$$
g^{\prime}\left(L^{D}\right)=\Delta+h^{\prime}\left(L^{E}\right)
$$

That is, the marginal return on lending in dollars exceeds that on lending in euros by a wedge that is exactly equal to the equilibrium CIP basis $\Delta$.

Let us first begin by considering what happens in a "normal" pre-crisis period when the probability $p$ of default by the Eurozone bank is zero. In this case, the bank can borrow all it wants to in the U.S. at the riskless rate, so as equation (6) makes clear, there is never any benefit to having a positive swap value $S$. It is possible, however, that for certain parameters, $L^{E}$ could exceed $X$, so that the bank faces increasing costs at the margin for raising retail euro deposits. If so, it could be cheaper to fund euro lending by borrowing in dollars and converting into euros, which would correspond to a negative value of $S$. To eliminate this uninteresting case, we assume that in normal times the pre-existing euro deposit base is equal to euro lending, so that 
when $p=0, L^{E}=X$. What we have in mind here is that the pre-crisis period represents a steady-state interval during which the bank has had the time to adjust its core deposits in its home country to match its loan balances. Indeed, Figure I shows that banks almost never have dollar liabilities in excess of dollar assets, which is consistent with this assumption.

Thus, optimal lending levels in normal times - which we denote $L^{D}(0)$ and $L^{E}(0)$ - just equate the marginal returns to lending in dollars and euros: $g^{\prime}\left(L^{D}(0)\right)=h^{\prime}\left(L^{E}(0)\right)$. Given our assumption that the capital constraint binds, this implies that $g^{\prime}\left(L^{D}(0)\right)=h^{\prime}\left(K-L^{D}(0)\right)$.

Next, consider what happens at the onset of a "crisis", by which we mean a period when $p>0$, i.e. when the probability of a Eurozone bank default rises to a strictly positive value. In this case, it always pays for the bank to borrow extra euros and convert them into dollars to fund some dollar lending. To see this, note that at $S=0$, the left-hand side of (6) is strictly positive: the marginal frictional cost of the swap and the marginal cost of increasing euro deposit funding are both zero at $S=0$, while the reduction in dollar funding costs, $\alpha p$, is positive. So $S=0$ can no longer be an equilibrium when $p>0$. Once we are in the region where swap usage is positive, and hence where there is a CIP deviation, we have the following proposition, which is proven in the appendix:

Proposition 1: If the capital constraint binds, an increase in the probability p of Eurozone bank default leads to less dollar lending, more euro lending, more swap activity, and an increase in the deviation from covered interest parity. For positive $p$, an increase in arbitrage capital, $W$, leads to more dollar lending, less euro lending, more swap activity and a decrease in the deviation from covered interest parity. 
The intuition behind proposition, which is proven in the appendix, is straightforward. When $p$ increases above zero, equation (6) tells us that the bank will react both by borrowing more in euros and by increasing the volume of its swap activity, thereby driving the CIP basis $\Delta$ upward. As equation (8) shows, this increase in the CIP basis represents a wedge in the relative cost of obtaining dollar funding versus euro funding, so at the margin the bank now allocates more of its fixed capital base to euro lending.

In our empirical work, we test the above comparative statics, using the money-market fund run on European banks in the second half of 2011 as a proxy for an aggregate shock to the value of $p$ for all European banks. Moreover, in addition to focusing on this time-series variation in $p$, we also consider a set of cross-sectional tests. At first glance, the model might appear unsuited to making cross-sectional predictions, since it is effectively a model of a single representative bank, or more accurately, of many identical banks of total measure one, since the bank we have been analyzing is assumed to be a price-taker in the swap market. However, the model is easily extended to incorporate some heterogeneity across banks.

Suppose we have two banks $i$ and $j$ that are otherwise similar, but with $\alpha_{i}>\alpha_{j}$, say because bank $i$ is more reliant on money-market funds than is bank $j$. Looking at equation (6), we can see that when $p$ rises above zero, both banks may become active in the swap market simultaneously, taking as given the common CIP basis of $\Delta$, but that bank $i$ will shift more of its funding to the euro market, thereby bearing a higher marginal cost of attracting retail depositors in that market. ${ }^{6}$ And bank $i$ will also, per equation (4), cut its dollar lending by more. Thus the model implies that the impact on dollar lending of a jump in $p$ should be more pronounced for

6. The only other modification that needs to be made when we introduce heterogeneity is to recognize that expression for the CIP basis is now more properly written as: $\Delta=\gamma^{2} \sum S /\left(W-\gamma \sum S\right)$. That is, it depends on the sum $\sum S$ of swap demands across the banks in the population. 
more money-fund-dependent banks. We test this additional implication of the model as well in what follows.

\section{DESCRIPTION OF THE DATA AND BACKGROUND FACTS}

This section describes our data sources and provides some background that will be useful for our empirical analysis. We discuss the syndicated loan market in the U.S. and Europe, and the important role that Eurozone banks play in the U.S. We also present data on Eurozone bank reliance on U.S. money-market funds, and note the problems they faced in tapping this financing source in the second half of 2011. Finally, we document that during this period there was a significant violation of covered interest parity. As the model shows, it is the combination of wholesale dollar funding difficulties and violations of covered interest parity that gives rise to a decline in dollar lending relative to euro lending.

\section{III.A. The Role of Eurozone Banks in the U.S. Syndicated Loan Market}

The loan data for our analysis come from Thompson Reuters’ DealScan database of loan origination. Almost all these loans are syndicated, i.e., originated by one or more "lead" banks and funded by a syndicate of banks and other investors. Often there are multiple lead banks originating a loan, and in these cases we prorate the loan amount by the number of lead banks in the syndicate. ${ }^{7}$ The country of the borrower and lender are based on the location of their headquarters as reported in DealScan.

Table I shows that European banks have a large presence in the U.S. syndicated loan market. During 2005-2007, the top European banks originated almost 24\% of syndicated loans

7. We consider a lead bank to be one that is designated as a "Lead Arranger" or "Agent" in the DealScan database. 
in the U.S., with about 11\% coming from Eurozone banks. The most prominent Eurozone banks in this regard are headquartered in France and Germany, each with about a 5\% market share. Banks headquartered in countries with sovereign debt problems—Greece, Ireland, Italy, Portugal and Spain—had a less than 2\% share of the U.S. market. Over 13\% of U.S. syndicated loans were originated by non-Eurozone European banks-mainly those located in the U.K. and Switzerland. These banks also do a lot of Eurozone lending and raise some of their deposits in euros. ${ }^{8}$ Given this euro deposit financing, there is a case for including these banks in our analysis, but we take the more conservative approach of reporting the results only for Eurozone banks. However, our results are robust to including European banks outside the Eurozone.

Table II highlights the fact that the syndicated loan market is global in nature; Eurozone and U.S. banks lend not just in their home regions, but throughout the world. The table also makes clear the importance of dollar lending. Indeed, outside of Europe, Eurozone banks do almost all of their lending in dollars. Even within Europe, Eurozone banks do a significant fraction of their lending in dollars-almost 9\% in the Eurozone and 30\% in the rest of Europe. Overall, $43 \%$ of Eurozone bank lending is in dollars. Given that most of their retail deposits are in euros, this creates a currency mismatch between their assets and retail deposits. The same is not true of U.S. banks, which do 89\% of their syndicated lending in dollars.

\section{[TABLES I \& II]}

\section{III.B. Eurozone Bank Reliance on U.S. Money-Market Funds and the Run in 2011}

In May 2011, financial markets became increasingly concerned about the exposure of European banks to Greek sovereign debt, amidst growing worries about the country's solvency.

8. Notoriously, the largest Icelandic banks had over two-third of their deposits in foreign currencies, most of it in euros. See "The Collapse of Iceland's Cross-Border Banks: Some Lessons for Deposits Insurance and Resolution Policies,” presentation made by Mar Gudmundsson, Governor of the Central Bank of Iceland, in the BIS conference held in Basel on June 9, 2011. 
Leading banks in France, Germany and Belgium were identified as having several billion euros of Greek sovereign bonds on their books. ${ }^{9}$ In response, investors began withdrawing money from U.S. prime money-market funds (MMFs), which, according to the SEC, had about one quarter of their assets invested in paper issued by Eurozone banks. The withdrawals were greater from those funds that had more exposure to Eurozone banks (Chernenko and Sunderam, 2014). This in turn led MMFs to reduce their holdings of instruments issued by Eurozone banks. As illustrated in Figure II, between May 2011 and June 2012, U.S. MMFs had reduced their exposure to Eurozone banks from 31\% to $8 \%$ of their total assets. French banks, which were top lenders to U.S. firms, on average lost over 75\% of their funding from U.S. MMFs (see Table III). However, after June 2012 as the crisis in the Eurozone began to stabilize, the MMF holdings of instruments issued by Eurozone banks begin to rebound.

The MMF withdrawal was an important shock to the ability of Eurozone banks to fund themselves in dollars. To measure the size of this shock for particular banks, we calculate the share of a bank's short-term funding that comes from U.S. MMFs as of the end of April 2011. This calculation is based on MMF security-level holdings compiled by Crane Data LLC from data provided by fund sponsors. These data cover roughly $85 \%$ of the universe of MMF holdings, with some smaller funds missing from the sample.

To compute the extent to which a Eurozone bank relied on MMFs for funding, we take the sum of MMF holdings of the bank's certificates of deposit (CDs), commercial paper (CP), asset-backed CP, repurchase agreements, and other short-term bank notes and deposits and scale this by the sum of the bank's deposits and short-term debt. Data on a bank's short-term liabilities are taken from Capital IQ and are measured as of the end of 2010. We should emphasize that we

9. E.g., see "Investors Count Cost to Banks of Greek Default," Financial Times, May 10, 2011 or “EU Banks' Risks from Greece Default Exceed Their Direct Exposures,” Moody’s Investors Services, May 15, 2011. 
are not scaling by banks' short-term dollar funding as that information is not available. Thus, our measure does not capture-and may greatly understate - the extent to which a bank relies on U.S. MMFs for its dollar funding specifically.

Ideally, we would also want to distinguish between insured and uninsured dollar funding. But there is very limited information on insured deposits, and almost none on insured deposits by currency. However, it is likely that the insured dollar deposits of Eurozone banks are limited. Only five of the large Eurozone banks operate in the U.S. through subsidiaries and, with some limited exceptions, only deposits of subsidiaries are eligible for FDIC insurance. On average, deposits reported to the FDIC by these five banks are roughly $82 \%$ of their MMF funding. For Deutsche Bank, deposits reported to the FDIC are only 43\% of its MMF funding.

Table III reports MMF funding reliance for the 11 Eurozone banks that were among the top fifty lenders in the U.S. syndicated loan market between 2005 and 2007. We also include MMF data for those European banks outside the Eurozone that were among the top 50 lenders. As can be seen, MMFs were an important source of short-term funding for these banks. For Deutsche Bank, the fifth-largest lender in the U.S., with $4.5 \%$ of syndicated origination volume, 7.7\% of its total short-term funding came from U.S. MMFs. The French banks-Societe Generale, Credit Agricole, BNP Paribas and Natixis-on average, received 5\% of their total short term funding from U.S. MMFs.

\section{[FIGURE II \&TABLE III]}

As noted above, these calculations understate the significance of MMFs as a source of dollar funding because they normalize by all short-term funding, including non-dollar deposits. While no systematic data are reported on funding currencies, information provided by Credit Agricole in a presentation to analysts can give a better sense of the dollar funding share of U.S. 
MMFs. ${ }^{10}$ The bank reported that in June 2011, 44\% of its short-term debt was in dollars. Based on data we have on Credit Agricole's short-term debt and MMF funding in April 2011, this implies that approximately 30\% of the bank's short-term dollar funding came from U.S. MMFs. Clearly, this implies a very meaningful reliance on the money-fund sector.

\section{III.C. Breakdown of Covered Interest Parity in 2011}

Foreign exchange swaps are the primary means through which global banks manage the currency mismatch between their assets and liabilities (e.g., Fender and McGuire, 2010). A swap contract enables a bank to exchange local currency for U.S. dollars at the current exchange rate, while agreeing to reverse the transaction-i.e., exchange U.S. dollars back to local currency—at the forward exchange rate. The typical maturity of a FX swap is three months, but as an overthe-counter instrument its maturity can be extended to several years. Counterparties typically post collateral, which is adjusted depending on movements in currencies.

In the absence of market frictions, the cost of an FX swap is pinned down by the differences in interest rates in the two currencies that are being swapped. Specifically, covered interest rate parity (CIP) implies that the differential in interest rates between two countries should be equal to the differential between the forward and spot exchange rates. Given this seemingly riskless arbitrage, significant CIP deviations have historically been rare (Taylor, 1987; Akram, Dagfinn and Sarno, 2008). However there have been repeated breakdowns in CIP since the beginning of the financial crisis in August of 2007. Coffey, Hrung and Sarkar (2009) document that after the Lehman bankruptcy in September of 2008, the U.S. dollar basis with respect to the euro shot up to over 200 basis points. More relevant for our study is that the basis

10. "Credit Agricole: Adapting to the New Environment" presentation made by Jean-Paul Chifflet, Chief Executive Officer in the Cheuvreux conference held in Paris on September 28, 2011. 
again rose dramatically in the second half of 2011, the period characterized by the money-fund pullback from European financial institutions. ${ }^{11}$

Panel A of Figure III shows the evolution of the euro basis. To construct this series we use daily quotes for 3-month German sovereign bills and 3-month U.S. T-bills, compiled from Bloomberg, as well as 3-month daily spot and forward exchange rates compiled by WM/Reuters and downloaded from Datastream. Our estimates for 2008 closely track Coffey, Hrung and Sarkar (2009). The CIP basis during the 2011-2012 funding shock was not nearly as large as it was during 2008 but was nevertheless substantial. As the dollar funding crisis abated after June 2012 the basis reverted back to modest levels. Another noteworthy observation, depicted in Panel B of Figure III, is that the CIP basis spike in 2011-2012 first shows up in the dollar-euro exchange rate. The subsequent widening of the dollar-yen and dollar-sterling bases may, according to the logic of our model, have been a spillover effect from Eurozone bank swap demand, driven in part by an aggregate scarcity of arbitrage capital across all currencies.

One crude way to get a handle on the potential magnitude of this swap demand is by noting that, according to the BIS, between the second and fourth quarters of 2011, Eurozone banks' net dollar position (dollar assets minus dollar liabilities) increased by $\$ 173$ billion, as compared to a drop of $\$ 98$ billion the year before, and a drop of $\$ 230$ billion the year after. Interestingly, this increase in currency mismatch is of the same rough magnitude as the decline in MMF holdings of Eurozone bank paper. And it is precisely this change in currency mismatch that Eurozone banks would presumably be seeking to hedge, thereby creating pressure on the CIP arbitrage relationship, and on arbitrageur capital positions sheets more generally. ${ }^{12}$

11. "Euro-Dollar Basis Swap Cost at 2008 Crisis Levels,” Wall Street Journal, November 16, 2011.

12. Buraschi, Menguturk and Sener (2015) connect the divergence in the rates on euro- and dollardenominated sovereign bonds for several emerging countries to frictions in banks' abilities to fund in foreign currency. 
[FIGURE III]

\section{LENDing BeHAVIOR FollOWING THE SHOCK TO MONEY-MARKET FundS}

In this section, we examine bank lending behavior around the MMF shock. We first show that Eurozone banks reduced their dollar-denominated loans relative to euro-denominated loans. Next, we document that this led to a reduction in the net supply of dollar credit to operating firms-i.e., the inward shift in loan supply by Eurozone banks was not fully offset by other lenders stepping into the breach. Finally, we show that those Eurozone banks that were most MMF-dependent reduced their lending by more than other Eurozone banks.

\section{IV.A. Direct Effects of MMF Shock on Bank Lending}

To examine the behavior of Eurozone banks around the MMF shock we construct a panel data set of bank-month observations from 2005-2013. We begin by focusing on the effect of the MMF shock on DOLLAR LOAN SHARE, the ratio of a bank's dollar-denominated loans to the sum of its dollar- and euro-denominated loans (excluding all other currencies). The exact specification is explained in the captions to each table.

The first column of Table IV reports the results of regressing the dollar loan share on SHOCK, a dummy variable that takes on the value one if the loan occurs between May 2011 and June 2012, the period during which Eurozone banks experienced the funding shock, and takes on the value zero if it occurs either in the pre-shock period leading up to May 2011 or in the postshock period from July 2012 - December 2013. Only the 11 Eurozone banks are included in this specification. As in all regressions in the table, we also include bank fixed effects since there is likely to be variation across banks in the extent to which they lend in dollars and euros.

As expected, the coefficient on SHOCK is negative and statistically significant. (Standard errors are calculated to allow for correlation of the error term across observations within a 
month. ${ }^{13}$ ) The coefficient in column (1) implies that Eurozone banks reduce their dollar loan share by 3.5 percentage points during the shock period relative to their pre- and post-shock period averages. Given that the dollar loan share has a sample mean of $17.7 \%$, this effect is fairly sizeable. Over the shock period, the 3.5 percentage-point change would have translated into a reduction of roughly $\$ 82$ billion in the origination of dollar syndicated loans. ${ }^{14}$ Column (2) repeats the exercise using the number of individual loans made in each currency instead of aggregate dollar and euro values to compute the loan share. The results are very similar.

In calculating the dollar loan share, we convert the value of euro-denominated loans into dollars, using the spot exchange rate at loan issuance, so these quantities can be meaningfully compared to one another. This raises the concern that an appreciation of the euro, as happened in the shock period, could mechanically lead to a decline in our DOLLAR LOAN SHARE variable, even if the nominal volume of loan issuance in each currency was unchanged. This mechanical effect could then potentially bias our inferences. To control for this possibility, throughout Table IV we add a control for the dollar/euro exchange rate. The coefficient on SHOCK is not sensitive to inclusion of this control. Interestingly, the coefficient on the exchange rate variable is significantly positive - the opposite of what one would expect if there was a purely mechanical effect at work. ${ }^{15}$

13. Any alternative clustering method strengthens our result.

14. This $\$ 82$ billion figure can be compared to our estimate that Eurozone banks lost approximately $\$ 370$ billion in dollar funding from U.S. money funds over the course of the shock period. What accounts for the difference in these numbers? First, as our model emphasizes, Eurozone banks presumably made up for a significant fraction of the lost dollar funding by turning to their domestic deposit bases. And second, it is important to bear in mind that the syndicated lending that we capture with our data is only a fraction of their total dollar lending — so that the total effect on dollar credit supply is likely somewhat larger than $\$ 82$ billion.

15. Why might a stronger euro lead to an increase in the share of dollar lending by Eurozone banks? One hypothesis is that if a Eurozone bank holds predominantly euro-denominated assets, then an increase in the value of the euro strengthens its economic capital relative to that of its U.S. counterparts. This in turns enables it to gain market share in those dollar-based loan markets where it is most likely to be in direct competition with U.S. banks. By contrast, in euro-based loan markets, where its competitors are 
The leading alternative explanation for the drop in the dollar lending share of Eurozone banks is that these banks experienced not a funding shock but rather a decline in dollar loan demand relative to euro loan demand. On its face, this alternative hypothesis is somewhat hard to motivate given that the source of the negative shock in the first place was the Eurozone. So, if anything, one would think that there would be more of a decline in the demand for eurodenominated loans. Nevertheless, we explore this alternative hypothesis in a number of ways.

First, in columns (3) and (4) we repeat the analysis of columns (1) and (2), but restrict the sample only to loans made in the European market. ${ }^{16}$ As can be seen, the estimated coefficients on SHOCK are very similar. This helps allay the concern that the results are picking up a relative shift in loan demand across European and American borrowers.

Next, in columns (5) through (8), we redo everything with U.S. banks included in the sample, and ask whether—as might be expected from a demand-side story—-the decline in the dollar loan share is also observed in these banks, which did not suffer from the same funding shock as the Eurozone banks. This is effectively a difference-in-difference specification. Specifically, we add to the sample seven U.S. banks that are active in syndicated lending in the Eurozone. The key coefficient of interest is now that on the variable EUROBANK*SHOCK, which is an interaction between the SHOCK dummy and a Eurozone bank dummy. Our fundingshock hypothesis implies that we should expect to see a negative coefficient. And indeed, the coefficient is negative and statistically significant. Moreover, the near-zero coefficient on the raw SHOCK term implies that there is no change in the currency composition of lending by U.S.

more likely to be other European banks, a movement in the exchange rate confers less of an advantage. The net result is an increase in the share of activity the European bank does in dollar markets. This logic is similar to that of Froot and Stein (1991).

16. As before, we only look at the euro and dollar denominated loans. 
banks in the shock period. In other words, the effect is specific to the Eurozone banks, consistent with our hypothesis.

\section{[TABLE IV]}

To more comprehensively control for potential demand-side confounds, in Table V we examine lending behavior at the loan level rather than at the bank level. We take advantage of the fact that we observe multiple instances in which the same firm taps the syndicated loan market, both before and after the shock. Thus we can ask whether when a given firm gets a dollar loan during the shock period, it is less likely to get it from a syndicate that includes one or more Eurozone lenders, as compared to the same firm borrowing outside of the shock period.

We now run regressions for the period 2000-2013; we look at a longer sample period so there are more repeated transactions per borrower. The unit of observation is a loan and the dependent variable is EUROBANK SHARE, the fraction of banks in the loan syndicate that are from the Eurozone. Importantly, we include firm fixed effects in the regressions. In the first two columns of Table $\mathrm{V}$ we consider only dollar loans, and the key variable of interest is SHOCK. As predicted, the coefficient on this variable is negative and statistically significant. In other words, in the wake of the dollar funding shock, Eurozone banks are less likely to appear in dollardenominated lending syndicates than otherwise, holding fixed the identity of the borrower.

Figure IV provides a graphical presentation of this finding. Here we simply regress EUROBANK SHARE on a sequence of monthly dummies and on firm fixed effects, and then plot the resulting time series of coefficients on the monthly dummies. As can be seen from the figure, the average monthly dummy is lower in the shock period than in the two surrounding non-shock periods, and the difference is statistically significant at the $1 \%$ level. 
In columns (3) through (5) of Table V, we add in euro-denominated loans along with the dollar-denominated loans, and the key coefficient of interest becomes that on DOLLAR $L O A N * S H O C K$. Thus now we are asking if the effect on syndicate composition that we saw in columns (1) and (2) is restricted only to those syndicates involving dollar-denominated loans, as the theory suggests it should be. As can be seen, the estimates uniformly bear out this hypothesis.

\section{[TABLE V \& FIGURE IV]}

While the results in Table V appear to be clear evidence that Eurozone banks reduced their loan supply during the shock period, the real effects of such a contraction would be minimal if other, non-Eurozone banks were able to step in and increase their supply of loans. However, this potential equilibrating response could be muted to the extent that corporate borrowers have the sort of information-intensive relationships with their existing Eurozone lenders that make shifting to another lender difficult (e.g., Sharpe, 1990; Rajan, 1992). Indeed, consistent with the imperfect substitution of new lenders for existing relationship lenders, Chodorow-Reich (2014) shows that during the 2007-9 financial crisis, firms that had previously borrowed from banks that were hit harder by the crisis had a more difficult time borrowing during the crisis, and those that were able to borrow did so on less favorable terms.

Thus, in the spirit of Chodorow-Reich (2014), we examine whether a firm is less likely to receive a new dollar-denominated loan during the shock period if it was more reliant on Eurozone banks for its dollar borrowing prior to the shock. Table VI presents this analysis. The sample includes all U.S. and European borrowers that received a dollar-denominated loan in the pre-shock period, and we ask how a given firm's likelihood of obtaining another dollardenominated loan—from any source-in the shock period depends on PAST EUROBANK 
SHARE, defined as the fraction of banks in its most recent pre-shock syndicate that are from the Eurozone. As can be seen, the effect of PAST EUROBANK SHARE is negative and statistically significant. A one standard-deviation change in this variable leads to a roughly 2 percentagepoint drop in the probability of getting a dollar loan over the shock period, which can be compared to an unconditional probability of getting a loan of $13.8 \%$. As Table VI details, this result is robust to inclusion of industry fixed effects, controls for year of the last loan origination (column (2)), controls for a variety of loan characteristics including the interest-rate spread on the prior loan, the loan amount, maturity and loan type (column (3)), and an alternative definition of PAST EUROBANK SHARE (column (4)) .

In Table VII, we examine the intensive, rather than extensive margin of loan supply. That is, we ask whether firms who had previously borrowed from Eurozone lenders are more likely to face higher rates if they do manage to borrow again during the shock period. Thus for those borrowers that obtain a new dollar loan during the shock period, we compute the change in interest rate spread charged over the London Interbank Offered Rate (LIBOR) as compared to their last pre-shock loan. We then regress this change in spread on PAST EUROBANK SHARE. Loan facilities for the shock period are matched to the pre-shock facilities of the same type, so as to make interest rate spreads as comparable as possible. ${ }^{17}$ Standard errors are clustered by borrower.

The results in Table VII indicate that borrowers that relied more heavily on Eurozone banks for their dollar borrowing before the shock end up paying a substantially higher interest rate on their loans during the shock period. The increase in the spread is approximately 40 basis points, which is quite sizable when compared to the pre-shock sample mean spread over LIBOR

17.We divide loan type in three categories: a revolving line, bank term loan, and institutional term loan. We exclude second-lien facilities from the sample. 
of 216 basis points. Moreover, this number may well understate the true effect because of a sample selection bias: we know from Table VI that some previously Eurobank-dependent firms are shut out of the market during the shock period, and it seems plausible to think that only the more creditworthy ones are able to obtain loans at all, and therefore make it into the sample analyzed in Table VII.

Taken together, the results in Tables VI and VII suggest that the contraction in dollar loan supply coming from the Eurozone banks during the shock period was not fully offset by other lenders, and hence represented a meaningful inward shift in the overall availability of credit to their customers. In other words, it appears that the shock to the Eurozone banks is likely to have translated into real effects.

\section{[TABLES VI \& VII]}

\section{IV.B. Cross-Sectional Effects on Bank Lending}

Finally, the model makes the cross-sectional prediction that those Eurozone banks that are the most money-fund-dependent will cut their dollar lending (relative to their euro lending) by more in response to the MMF shock. We operationalize this prediction by measuring moneyfund dependence as the fraction of short-term funding that comes from U.S. money funds, as reported in Table III and discussed above. Recall that this measure, MMFSHARE, normalizes by all short-term debt, both dollar- and euro-denominated.

In Table VIII we use the same specification as Table V, column (2). The dependent variable is still DOLLAR LOAN SHARE, the fraction of a bank's loans that are in dollars, but we separate Eurozone banks into those that, as of April 2011, had over 4\% of their short-term funding coming from U.S. MMFs (the most MMF-exposed banks) and those that had less than $4 \%$ of their short term funding coming from U.S. MMFs (the least MMF-exposed banks). 
[TABLE VIII]

The first column of Table VIII shows that the coefficient on SHOCK for the most MMFexposed Eurozone banks is negative and statistically significant. By contrast, the second column shows that the effect of SHOCK for the least MMF-exposed banks the effect is much smaller and is not statistically significant. An F-test reveals that the coefficients from the two different groups are statistically different from each other at 5\% level. One should probably not overinterpret this finding, given the small number of banks in each of the groups, but it is at least directionally consistent with what one would expect based on our model.

\section{CONCLUSIONS}

In this paper, we have shown that one of the consequences of the European sovereign debt crisis was that Eurozone banks cut their dollar-denominated lending. This is not surprising in itself; one would expect these banks to cut lending in the face of capital and liquidity constraints stemming from losses on their portfolios of sovereign bonds. More interestingly, however, we show that Eurozone banks shifted the composition of their dollar and euro lending, cutting their dollar lending by more, despite the fact that European economies were more immediately threatened by the debt crisis.

We argue that this phenomenon reflects two features of the markets in which European banks fund themselves. First, European banks rely on uninsured and relatively flighty wholesale dollar funding sources to finance their dollar lending whereas a good deal of their euro lending is financed with stickier euro deposits. Second, frictions in the foreign exchange swap market limit the extent to which Eurozone banks can effectively use euro deposits to fund their dollar lending. As swap demand from Eurozone banks rises, there is only limited arbitrage capital available to take the other side of the trade, which increases the cost of engaging in this synthetic dollar 
borrowing. Thus Eurozone banks adjust to strains in wholesale dollar funding markets by borrowing more in euros, but also by cutting back their dollar lending relative to euro lending. This, in turn, adversely affects the dollar borrowers of Eurozone banks; they are less likely raise additional funding and when they do so, the funding is on less attractive terms.

The perspective on global banks developed in this paper highlights the fragilities associated with a particular foreign-bank business model, which involves banks funding large volumes of activity outside their home currency with uninsured short-term sources of wholesale finance. A somewhat different lens on these fragilities is provided by Giannetti and Laeven (2012a, 2012b), who document a generalized "flight home" effect in bank lending behavior during periods of financial stress. Specifically, global banks tend to reduce their lending share abroad relative to their lending share in their home countries when either: (i) there is a banking crisis in their home country; or (ii) credit spreads in the domestic interbank market go up. Although our theory has led us to focus on measuring lending activity by currency, rather than by country, we suspect that there is some overlap in the two phenomena, and that the mechanism we have proposed here may be helpful in understanding these broad-based flight-home effects.

Stretching somewhat further, it is well-known that in addition to cross-border lending, global trade flows also tend to contract during periods of economic and financial stress, with the Great Recession providing a particularly stark example. Amiti and Weinstein (2011) argue that this effect reflects the importance of bank lending in trade finance-in other words, when banks are constrained, they have difficulty lending to exporters, which in turn leads to a reduction in international trade. In their empirical tests, Amiti and Weinstein (2011) point to bank capital (which they proxy for with banks' stock-market valuations) as the relevant metric of bank health. While bank capital is surely important, our work adds a potential further nuance to their story: to 
the extent that trade finance is particularly reliant on global banks that can lend outside of their domestic currencies, it may be especially vulnerable-perhaps more so than other types of purely domestic activity that are also bank-dependent—not only to changes in bank capital positions, but also to shocks to banks' ability to raise uninsured wholesale funding outside of their domestic currency. ${ }^{18}$

In addition to these positive implications, our framework may be helpful in thinking about a number of policy issues related to global banks. For example, in February of 2014, the Federal Reserve finalized a rule imposing enhanced prudential standards on foreign banking organizations. ${ }^{19}$ One part of the rule requires the U.S. branches and agencies of foreign banks to hold a prescribed stock of liquid assets, in part as a buffer against potential funding outflows. This sort of regulation would seem to be well-motivated by the results in this paper.

Our theoretical framework also sheds light on the Fed's provision of dollar swap lines to the European Central Bank and other central banks during the period of stress in dollar funding markets. One way to think of these swap lines is that they were a device to alleviate the frictions associated with limited arbitrage and the accompanying CIP violations. By making dollars available to the ECB — which could then on-lend these dollars to Eurozone banks—-the burden on the currency swap market as a device for generating synthetic dollar funding was presumably reduced.

18. To take a concrete example: consider an Italian auto manufacturer that exports cars to the U.S. In so doing, it may incur dollar-denominated payables that it needs finance-because it ships the cars and only receives payment in dollars say 60 days later. If its closest relationship is with an Italian bank, it might count on the Italian bank for the dollar trade finance. And then, in a period of financial stress, even if the Italian bank has plenty of equity capital, it might be less able to provide dollar loans to the auto manufacturer if, per the mechanism we describe, it is having trouble raising dollar funding.

19. The Federal Register notice describing the rule is available at

http://www.federalreserve.gov/newsevents/press/bcreg/20140218a.htm 
From an ex ante perspective, this same logic also suggests that there may be some underappreciated tradeoffs associated with the dollar's status not only as a global reserve currency, but also as a global funding currency. The fact that so many non-U.S. operating firms do some of their business in dollars, and often rely on non-U.S. banks to accommodate their credit needs, may imply that lending terms in all dollar-denominated credit markets, including those facing purely domestic U.S. borrowers, are more exposed than they otherwise would be to shocks emanating from abroad. One consequence of this exposure is that the Federal Reserve may find itself in a position of having to intervene to manage these disruptions-e.g., via the provision of swap lines-in a broader range of circumstances than it would if the dollar were not so prominent as a global funding currency. Indeed, the Fed's enhanced prudential standards on foreign banking firms can be thought of in part as an attempt to reduce this ex ante reliance on its own balance sheet.

HARVARD UNIVERSITY AND NBER HARVARD UNIVERSITY AND NBER HARVARD UNIVERSITY AND NBER 


\section{APPENDIX}

Proof of Proposition 1: First, note that for all $p>0$, equation (6) implies that $S>0$. This fact, along with our assumption that $L^{E}=X$, allows us to re-write the two first-order conditions for $L^{D}$ and $S$ as:

$$
\begin{aligned}
& \alpha p-\frac{\gamma^{2} S}{W-\gamma S}-\phi\left(K-L^{D}+S-X\right)=0, \\
& g^{\prime}\left(L^{D}\right)-h^{\prime}\left(K-L^{D}\right)-\frac{\gamma^{2} S}{W-\gamma S}=0
\end{aligned}
$$

Implicitly differentiating $(A .1)$ and $(A .2)$ with respect to $p$, and solving these simultaneous equations, yields the following comparative statics:

$$
\begin{gathered}
\frac{d S}{d p}=\alpha\left\{\frac{\gamma^{2} W}{(W-\gamma S)^{2}}\left(1-\frac{\phi}{g^{\prime \prime}\left(L^{D)}+h^{\prime \prime}\left(K-L^{D}\right)\right.}\right)+\phi\right\}^{-1}>0 \\
\frac{d L^{D}}{d p}=\frac{\gamma^{2} W /(W-\gamma S)^{2}}{g^{\prime \prime}\left(L^{D)}+h^{\prime \prime}\left(K-L^{D}\right)\right.} \frac{d S}{d p}<0
\end{gathered}
$$

Given the binding capital constraint, it follows that $\frac{\partial L^{E}}{\partial p}>0$. Also because $S$ is increasing in $p$, it follows from (1) that $\Delta$, the deviation from CIP, is also increasing in $p$.

To derive the comparative statics with respect to arbitrage capital, $W$, one can do similar calculations to yield:

$$
\begin{aligned}
& \left.\frac{d S}{d W}=\frac{\gamma^{2} S}{(W-\gamma S)^{2}}\left\{\frac{\gamma^{2} W}{(W-\gamma S)^{2}}+\frac{\phi\left(g^{\prime \prime}\left(L^{D)}+h^{\prime \prime}\left(K-L^{D}\right)\right)\right.}{g^{\prime \prime}\left(L^{D}\right)+h^{\prime \prime}\left(K-L^{D}\right)-\phi}\right)\right\}^{-1}>0 \\
& \frac{d L^{D}}{d W}=\frac{\phi}{\phi-g^{\prime \prime}\left(L^{D}\right)-h^{\prime \prime}\left(K-L^{D}\right)} \frac{d S}{d W}>0 \\
& \frac{d \Delta}{d W}=\frac{\gamma^{2} S}{(W-\gamma S)^{2}}\left\{\frac{\gamma^{2} W}{(W-\gamma S)^{2}} \frac{\phi-g^{\prime \prime}\left(L^{D}\right)+h^{\prime \prime}\left(K-L^{D}\right)}{\phi\left(g^{\prime \prime}\left(L^{D)}+h^{\prime \prime}\left(K-L^{D}\right)\right)\right.}-1\right\}^{-1}<0
\end{aligned}
$$


An increase in arbitrage capital means that a given volume of swaps generates less of a deviation from CIP. Thus, for $p>0$ banks will want to borrow more in euros and to fund dollar lending. This leads to an increase in dollar lending, less euro lending and more swap activity in equilibrium. 


\section{REFERENCES}

Acharya, Viral, Gara Alonso, and Anna Kovner. "How do Global Banks Scramble for Liquidity? Evidence from the Asset-Backed Commercial Paper Freeze of 2007,” Federal Reserve Bank of New York Staff Reports, 623 (August 2013).

Acharya, Viral, and Philipp Schnabl. "Do Global Banks Spread Global Imbalances? AssetBacked Commercial Paper during the Financial Crisis of 2007-09,” IMF Economic Review, 58 (2010), 37-73.

Akram, Q. Farooq, Rime Dagfinn, and Lucio Sarno. “Arbitrage in the Foreign Exchange Market: Turning on the Microscope,” Journal of International Economics, 76 (2008), 237-253.

Amiti, Mary, and David E. Weinstein. “Exports and Financial Shocks,” Quarterly Journal of Economics, 126 (2011), 1841-1877.

Baba, Naohiko, Frank Packer, and Teppei Nagano. "The Spillover of Money Market Turbulence to FX Swap and Cross-Currency Swap Markets,” BIS Quarterly Review, (2008), 73-86.

Becker, Bo, and Victoria Ivashina. "Cyclicality of Credit Supply: Firm Level Evidence,” Working paper, 2014.

Bottazzi, Jean-Marc, Jaime Luque, Mario Pascoa, and Suresh Sundaresan. “Dollar Shortage, Central Bank Actions, and the Cross Currency Basis,” Working paper, 2012.

Buraschi, Andrea, Murat Menguturk, and Emrah Sener. "The Geography of Risk Capital,” Review of Financial Studies, 28 (2015), 1103-1152.

Chernenko, Sergey, and Adi Sunderam. "Frictions in Shadow Banking: Evidence from the Lending Behavior of Money Market Mutual Funds,” Review of Financial Studies, 27 (2014), 1717-1750.

Cetorelli, Nicola, and Linda S. Goldberg. “Global Banks and International Shock Transmission: Evidence from the Crisis,” IMF Economic Review, 59 (2011), 41-76.

Cetorelli, Nicola, and Linda S. Goldberg. "Follow the Money: Quantifying Domestic Effects of Foreign Bank Shocks in the Great Recession,” American Economic Review (Papers and Proceedings), 102 (2012), 213-218.

Cetorelli, Nicola, and Linda S. Goldberg. “Liquidity Management of U.S. Global Banks: Internal Capital Markets in the Great Recession,” Journal of International Economics, 88 (2012), 299-311. 
Chava, Sudheer, and Amiyatosh Purnanandam. "The Effect of Banking Crisis on BankDependent Borrowers,” Journal of Financial Economics, 99 (2011), 116-135.

Chodorow-Reich, Gabriel. “The Employment Effects of Credit-Market Disruptions: Firm Level Evidence from the 2008-9 Financial Crisis,” Quarterly Journal of Economics, 129 (2014), 1-59.

Coffey, Niall, Warren Hrung and Asani Sarkar. "Capital Constraints, Counterparty Risk, and Deviations from Covered Interest Rate Parity,” Federal Reserve Bank of New York Staff Reports, 393 (October 2009).

Correa, Ricardo, Horacio Sapriza, and Andrei Zlate. "Liquidity Shocks, Dollar Funding Costs and the Bank Lending Channel during the European Sovereign Crisis,” Working paper, 2012.

Fender, Ingo, and Patrick McGuire. "Bank Structure, Funding Risk and the Transmission of Shocks across Countries: Concepts and Measurements,” BIS Quarterly Review, (September 2010), 63-79.

Froot, Kenneth A., and Jeremy Stein. "Exchange Rates and Foreign Direct Investment: An Imperfect Capital Market Approach,” Quarterly Journal of Economics, 4 (1991) 11911217.

Garleanu Nicolae, and Lasse Pedersen. "Margin-Based Asset Pricing and Deviations from the Law of One Price,” Review of Financial Studies, 24 (2011), 1980-2022.

Giannetti, Mariassunta, and Luc Laeven. "The Flight Home Effect: Evidence from the Syndicated Loan Market During Financial Crises,” Journal of Financial Economics, 104 (2012), 23-43.

Giannetti, Mariassunta, and Luc Laeven. "Flight Home, Flight Abroad, and International Credit Cycles,” American Economic Review Papers and Proceedings, 102 (2012), 219-224.

Griffolli, Tommaso Mancini, and Angelo Ranaldo. "Limits to Arbitrage during the Crisis: Funding Liquidity Constraints and Covered Interest Parity,” Swiss National Bank Working Paper, 2011.

Kashyap, Anil, Owen Lamont, and Jeremy Stein. "Credit Conditions and the Cyclical Behavior of Inventories,” Quarterly Journal of Economics, 109 (1994), 565-592.

Levich, Richard. "FX Counterparty Risk and Trading Activity in Currency Forward and Future Markets,” Review of Financial Economics: 21 (2012), 102-110. 
Myers, Stewart, and Nicholas Majluf. "Corporate Financing and Investment Decisions When Firms Have Information that Investors Do Not Have,” Journal of Financial Economics, 13 (1994), 187-221.

Peek, Joe, and Eric S. Rosengren. "The International Transmission of Financial Shocks: The Case of Japan,” American Economic Review, 87 (1997), 495-505.

Peek, Joe, and Eric S. Rosengren. "Collateral Damage: Effects of the Japanese Bank Crisis on Real Activity in the United States," American Economic Review, 90 (2000), 30-45.

Schnabl, Philipp. "The International Transmission of Bank Liquidity Shocks: Evidence from an Emerging Market,” Journal of Finance, 67 (2012), 897-932.

Shin, Hyun Song. “Global Banking Glut and Loan Risk Premium,” IMF Economic Review, 60 (2012), 155-192.

Taylor, Mark. "Covered Interest Parity: A High-Frequency, High-Quality Data Study," Economica, 54 (1987), 429-438. 


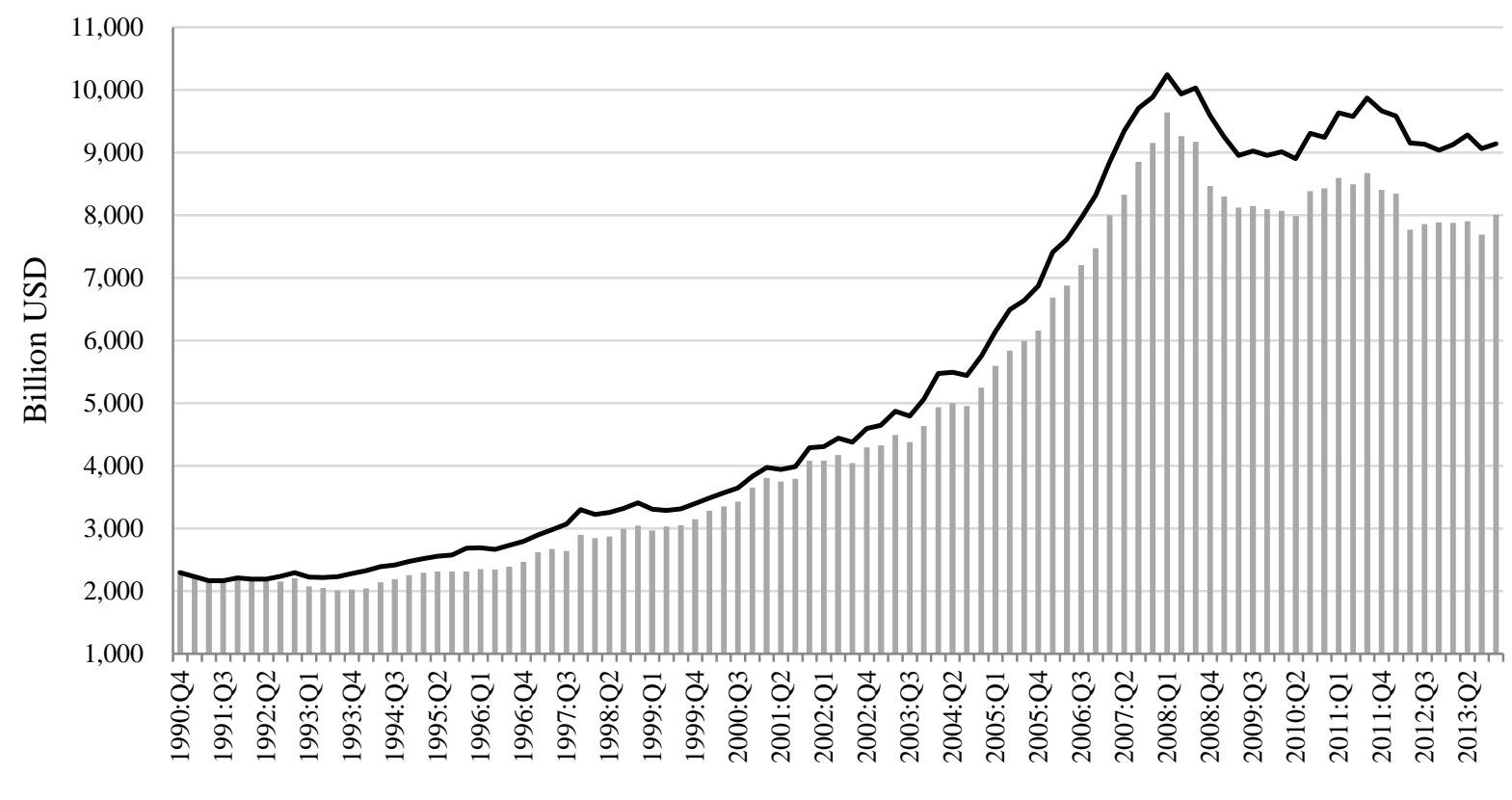

U.S. dollars liabilities —U.S. dollars assets

FIGURE I

Dollar Assets and Liabilities of Foreign Banks

Compiled from Bank of International Settlement locational banking statistics, July 2014. 


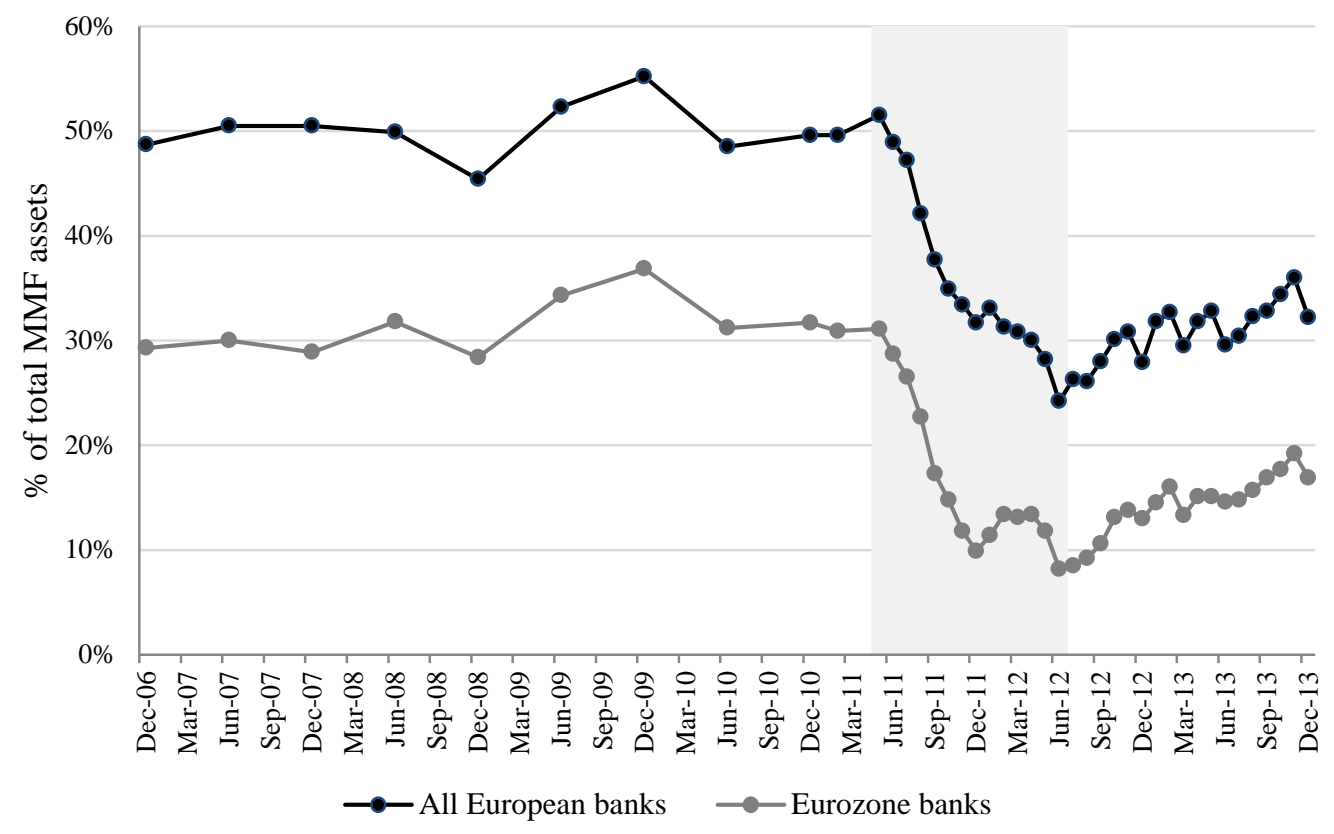

FIGURE II

Money-Market-Fund Exposure to European Banks

The figure shows the fraction of money-market-fund assets invested in liabilities of European and Eurozone banks. Data is from Fitch Ratings, "U.S. Money Fund Exposure and European Banks," February 4, 2014. The data is monthly starting in February 2011, semiannual before that. The highlighted area corresponds to the period May 2011 through June 2012. 
(a) Euro basis, January 2007- December 2013

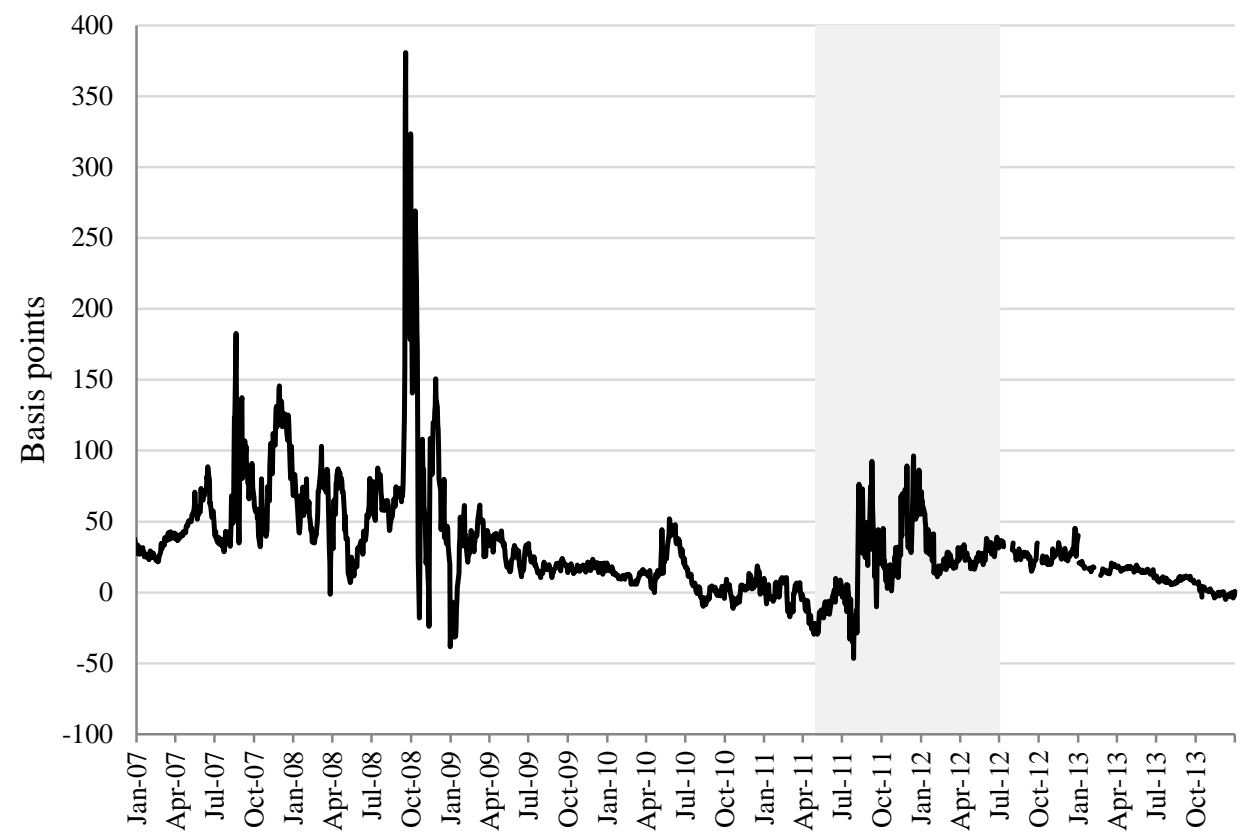

(b) Other currencies, July 2010 - December 2013

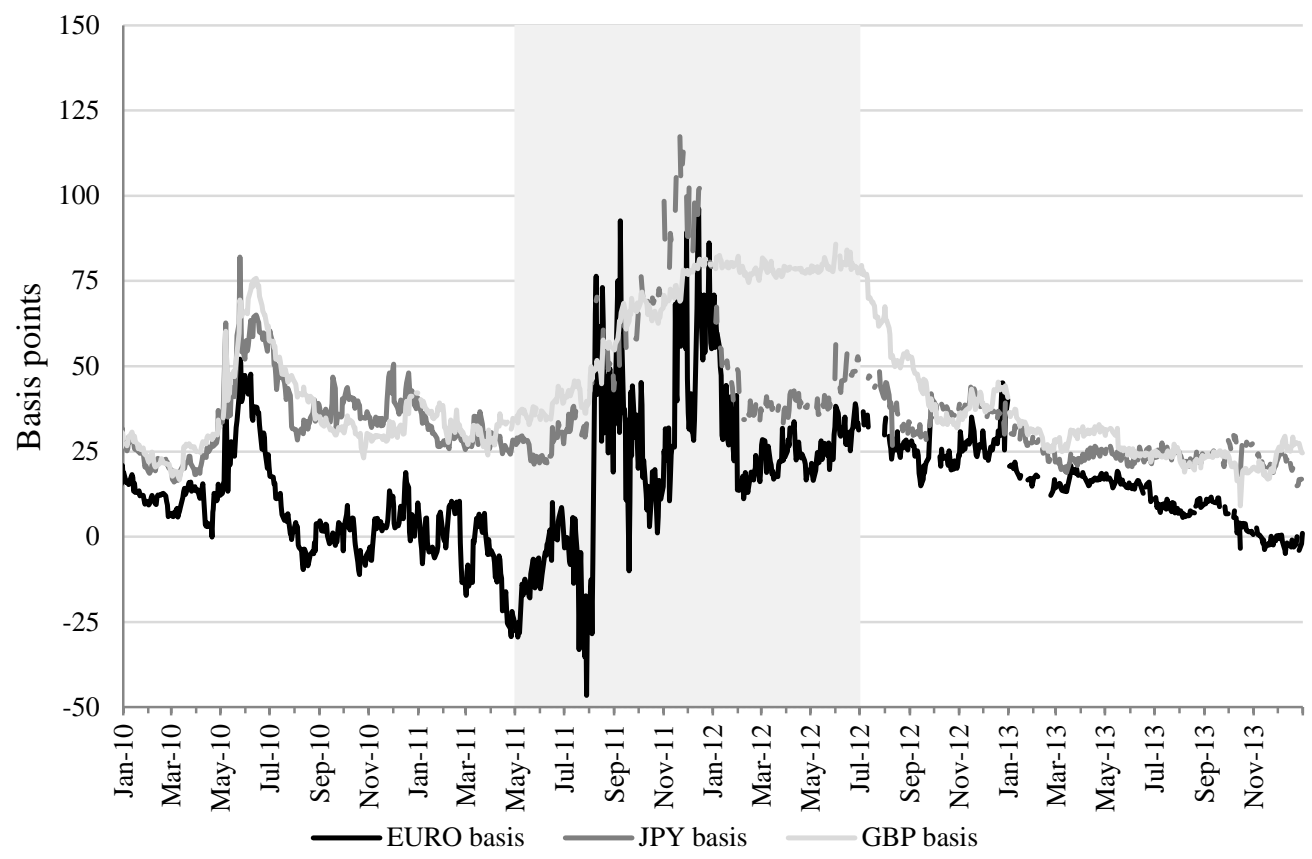

FIGURE III

Deviations from Covered Interest Parity

The basis is constructed using sovereign bonds rates. Daily quotes for 3-month sovereign rates are from Bloomberg, and 3-month daily spot and forward rates are compiled by WM/Reuters and downloaded from Datastream. The highlighted area corresponds to May 2011 through June 2012. 


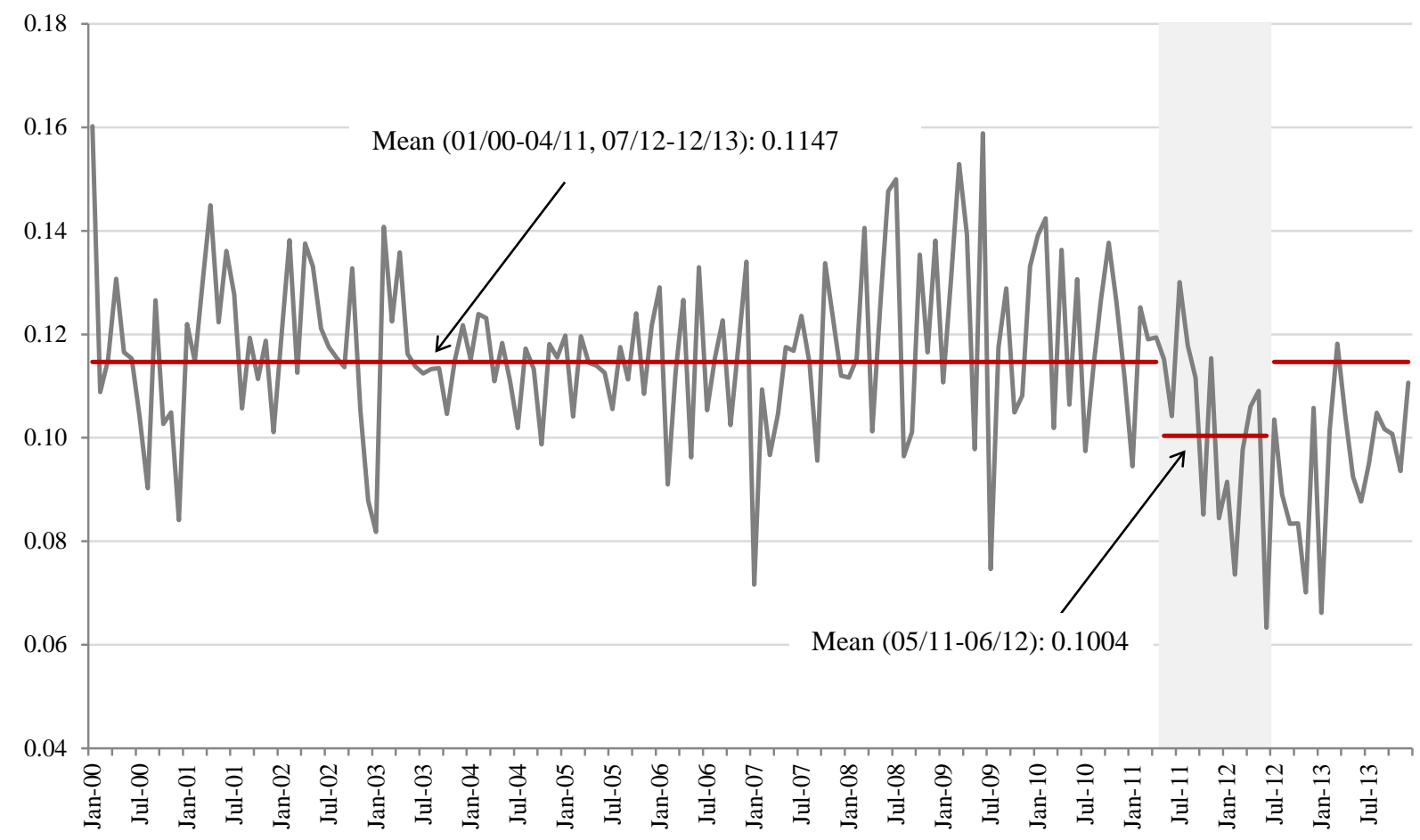

\section{FIGURE IV}

CHOICE OF LENDER FOR DOLLAR-DENOMINATED LOANS

This figure illustrates graphically the source of identification in the regressions reported in Table V. The plotted series corresponds to the coefficients $\left(\beta_{t}\right)$ on the monthly dummies of the following specification:

$$
\text { EUROBANK SHARE } E_{j t}=D_{j}+\beta_{t} D_{t}+X_{j},
$$

where the $D_{j}$ are borrower fixed effects, the $D_{t}$ are month fixed effects and $X_{j}$ is loan size. The sample includes U.S. dollar denominated loans issued in Europe and U.S. The highlighted area corresponds to May 2011 through June 2012. The difference between average $\beta_{t}$ for this period and the rest of the sample $(0.1147-0.1004=-0.0143)$ is equivalent to the coefficient on SHOCK in specification (2) in Table V. However, the magnitudes are not exactly the same because the panel is unbalanced. 
TABLE I

MARKET SHARE, LARGEST LENDERS IN EUROZONE, 2005-2007

\begin{tabular}{|c|c|c|c|c|c|}
\hline & \multirow[t]{2}{*}{ Market: } & \multicolumn{2}{|c|}{ Share of Eurozone lending } & \multicolumn{2}{|c|}{ Market share U.S. } \\
\hline & & Lead & All lenders & Lead & All lenders \\
\hline \multicolumn{6}{|l|}{ Europe, “GIIPS”: } \\
\hline UniCredit & Italy & 3.02 & 3.21 & 0.05 & 0.31 \\
\hline Banco Bilbao Vizcaya Argentaria & Spain & 2.33 & 2.23 & 0.06 & 0.43 \\
\hline Intesa Sanpaolo & Italy & 1.91 & 2.14 & 0.04 & 0.26 \\
\hline Banco Santander & Spain & 2.37 & 2.32 & 0.10 & 0.44 \\
\hline Mediobanca & Italy & 0.99 & 1.07 & -- & -- \\
\hline Banco Financiero y de Ahorros & Spain & 0.90 & 1.00 & 0.01 & 0.04 \\
\hline La Caja de Barcelona & Spain & 0.78 & 0.77 & -- & -- \\
\hline Banco de Sabadell & Spain & 0.32 & 0.35 & -- & -- \\
\hline Bank of Ireland Group & Ireland & 0.30 & 0.45 & 0.05 & 0.24 \\
\hline ICO [Instituto de Credito Oficial] & Spain & 0.23 & 0.26 & -- & -- \\
\hline \multicolumn{6}{|l|}{ France: } \\
\hline BNP Paribas & France & 6.70 & 5.07 & 2.31 & 2.36 \\
\hline Credit Agricole & France & 4.91 & 4.29 & 1.03 & 1.25 \\
\hline Societe Generale & France & 4.57 & 3.64 & 0.48 & 1.02 \\
\hline Natixis SA & France & 3.01 & 3.22 & 0.09 & 0.47 \\
\hline CM-CIC & France & 1.32 & 1.72 & 0.00 & 0.06 \\
\hline \multicolumn{6}{|l|}{ BeNeLux: } \\
\hline ING Group & Netherlands & 2.72 & 2.47 & 0.33 & 0.81 \\
\hline Fortis Bank & Belgium & 1.71 & 1.89 & 0.38 & 0.66 \\
\hline Rabobank & Netherlands & 0.78 & 0.96 & 0.30 & 0.41 \\
\hline KBC Group & Belgium & 0.47 & 0.74 & 0.02 & 0.28 \\
\hline Dexia Bank & Belgium & 0.46 & 0.65 & 0.02 & 0.06 \\
\hline \multicolumn{6}{|l|}{ Rest of Eurozone: } \\
\hline Commerzbank & Germany & 4.92 & 4.74 & 0.50 & 0.90 \\
\hline Deutsche Bank & Germany & 4.74 & 3.50 & 4.47 & 3.25 \\
\hline WestLB & Germany & 1.32 & 1.41 & 0.14 & 0.29 \\
\hline BayernLB & Germany & 1.13 & 1.22 & 0.07 & 0.23 \\
\hline Landesbank Baden-Wurttemberg & Germany & 0.98 & 1.14 & 0.01 & 0.04 \\
\hline Landesbank Hessen-Thuringen [Helaba] & Germany & 0.42 & 0.62 & 0.04 & 0.08 \\
\hline DZ Bank & Germany & 0.42 & 0.56 & 0.01 & 0.10 \\
\hline KfW Bankengruppe & Germany & 0.41 & 0.68 & 0.00 & 0.01 \\
\hline HSH Nordbank & Germany & 0.38 & 0.38 & 0.06 & 0.09 \\
\hline NordLB Group & Germany & 0.24 & 0.31 & 0.03 & 0.08 \\
\hline Total Eurozone: & & 54.77 & 53.00 & 10.61 & 14.15 \\
\hline \multicolumn{6}{|l|}{ Rest of Europe: } \\
\hline Svenska Handelsbanken & Sweden & 0.31 & 0.26 & -- & -- \\
\hline SEB Merchant Banking & Sweden & 0.29 & 0.40 & -- & 0.04 \\
\hline Nordea Bank AB & Sweden & 0.45 & 0.46 & 0.03 & 0.09 \\
\hline Credit Suisse & Switzerland & 1.60 & 1.64 & 3.76 & 0.09 \\
\hline UBS & Switzerland & 1.26 & 1.23 & 1.73 & 3.37 \\
\hline Royal Bank of Scotland & UK & 9.21 & 7.71 & 3.87 & 2.01 \\
\hline Barclays Bank & UK & 3.16 & 2.87 & 2.27 & 3.77 \\
\hline HSBC & UK & 3.08 & 2.87 & 1.18 & 2.07 \\
\hline Lloyds Banking Group & UK & 1.01 & 1.33 & 0.39 & 1.57 \\
\hline Total Europe: & & 75.14 & 71.75 & 23.86 & 27.68 \\
\hline \multicolumn{6}{|l|}{ US: } \\
\hline Citi & USA & 5.66 & 4.03 & 11.45 & 6.70 \\
\hline JP Morgan & USA & 3.75 & 3.13 & 17.08 & 10.13 \\
\hline Bank of America Merrill Lynch & USA & 1.86 & 1.94 & 16.15 & 9.83 \\
\hline Goldman Sachs & USA & 1.68 & 1.79 & 2.55 & 2.71 \\
\hline Morgan Stanley & USA & 1.32 & 1.43 & 1.68 & 2.16 \\
\hline Lehman Brothers & USA & 0.52 & 0.60 & 2.26 & 2.18 \\
\hline GE Capital & USA & 0.52 & 0.56 & 2.36 & 2.29 \\
\hline Total U.S.: & & 15.29 & 13.49 & 53.53 & 36.00 \\
\hline \multicolumn{6}{|l|}{ Other: } \\
\hline Mitsubishi UFJ Financial Group & Japan & 2.27 & 2.47 & 1.85 & 2.45 \\
\hline Mizuho Financial Group & Japan & 0.96 & 1.08 & 0.56 & 1.35 \\
\hline Sumitomo Mitsui Financial Group & Japan & 0.41 & 0.61 & 0.37 & 0.98 \\
\hline Total other: & & 3.64 & 4.15 & 2.78 & 4.77 \\
\hline
\end{tabular}

Notes. Loan amount is prorated based on the number of the lead banks ("Lead") or based on the total number of syndicate participants ("All lenders"). Lead bank is identified based on whether the lender is designated as "Lead Arranger" or "Agent” in the league tables as reported in DealScan. The table reports the top 50 lenders in the Eurozone; Banesto's share is aggregated together with Santander's share. Note that Lehman Brothers went bankrupt in 2008, and Fortis was acquired by BNP Paribas in 2009. 
TABLE II

SYNDICATED LENDING AROUND THE WORLD BY CURRENCY, 2005-2007

\begin{tabular}{|c|c|c|c|c|c|c|}
\hline & $\begin{array}{l}\text { Lending in } \\
\text { the region }\end{array}$ & $\begin{array}{l}\% \text { of Total } \\
\text { lending }\end{array}$ & $\begin{array}{c}\text { Lending in } \\
\text { Euro } \\
\text { (billion USD) }\end{array}$ & $\begin{array}{c}\text { Lending in } \\
\text { USD } \\
\text { (billion USD) }\end{array}$ & $\begin{array}{l}\text { Lending in } \\
\text { Euro } \\
(\%)\end{array}$ & $\begin{array}{c}\text { Lending in } \\
\text { USD } \\
(\%)\end{array}$ \\
\hline \multicolumn{7}{|l|}{ Eurozone banks: } \\
\hline Eurozone & $1,036.15$ & $45.5 \%$ & 941.64 & 89.11 & $90.9 \%$ & $8.6 \%$ \\
\hline Rest of Europe & 420.64 & $18.5 \%$ & 124.04 & 127.12 & $29.5 \%$ & $30.2 \%$ \\
\hline U.S. & 495.52 & $21.8 \%$ & 4.30 & 490.53 & $0.9 \%$ & $99.0 \%$ \\
\hline Rest of North America & 17.89 & $0.8 \%$ & 0.00 & 14.47 & $0.0 \%$ & $80.9 \%$ \\
\hline Asia & 139.44 & $6.1 \%$ & 10.06 & 102.92 & $7.2 \%$ & $73.8 \%$ \\
\hline Latin America & 81.09 & $3.6 \%$ & 2.27 & 78.81 & $2.8 \%$ & $97.2 \%$ \\
\hline Middle East & 63.25 & $2.8 \%$ & 3.40 & 59.78 & $5.4 \%$ & $94.5 \%$ \\
\hline Africa & 21.27 & $0.9 \%$ & 1.74 & 17.65 & $8.2 \%$ & $83.0 \%$ \\
\hline Total: & $2,275.25$ & & $1,087.46$ & 980.39 & $47.8 \%$ & $43.1 \%$ \\
\hline \multicolumn{7}{|l|}{ U.S. banks: } \\
\hline Eurozone & 313.96 & $7.8 \%$ & 252.06 & 60.53 & $80.3 \%$ & $19.3 \%$ \\
\hline Rest of Europe & 234.74 & $5.8 \%$ & 41.48 & 75.46 & $17.7 \%$ & $32.1 \%$ \\
\hline U.S. & $3,269.47$ & $80.8 \%$ & 7.82 & 3,255.99 & $0.2 \%$ & $99.6 \%$ \\
\hline Rest of North America & 56.83 & $1.4 \%$ & 0.12 & 47.79 & $0.2 \%$ & $84.1 \%$ \\
\hline Asia & 89.91 & $2.2 \%$ & 5.56 & 60.11 & $6.2 \%$ & $66.9 \%$ \\
\hline Latin America & 56.79 & $1.4 \%$ & 0.41 & 56.38 & $0.7 \%$ & $99.3 \%$ \\
\hline Middle East & 15.54 & $0.4 \%$ & 0.16 & 15.38 & $1.0 \%$ & $99.0 \%$ \\
\hline Africa & 10.24 & $0.3 \%$ & 0.32 & 8.69 & $3.1 \%$ & $84.9 \%$ \\
\hline Total: & $4,047.48$ & & 307.93 & $3,580.33$ & $7.6 \%$ & $88.5 \%$ \\
\hline
\end{tabular}

Notes. Loan amount is prorated based on the number lead banks receiving league table credit. 
TABLE III

U.S. PRIME MONEY-MARKET FundS AS A Funding SOURCE

\begin{tabular}{llrr}
\hline \hline \multicolumn{1}{c}{ Bank } & \multicolumn{1}{c}{ Country } & $\begin{array}{r}\text { MMF reliance } \\
\text { as of April 2011 } \\
(\%)\end{array}$ & $\begin{array}{r}\text { Change in MMF reliance, } \\
\text { April 2011 to June 2012 } \\
(\%)\end{array}$ \\
\hline Eurozone: & Germany & 7.65 & $2.4 \%$ \\
Deutsche Bank & Netherlands & 7.63 & $-2.7 \%$ \\
Rabobank & France & 6.25 & $-67.6 \%$ \\
Societe Generale & Netherlands & 5.14 & $-27.8 \%$ \\
ING Bank & France & 5.06 & $-100 \% *$ \\
Natixis & France & 4.28 & $-82.3 \%$ \\
Credit Agricole & France & 4.25 & $-77.1 \%$ \\
BNP Paribas & Germany & 1.90 & $-100 \% *$ \\
Commerzbank & Spain & 1.25 & $-100 \% *$ \\
Banco Bilbao Vizcaya Argentaria & Italy & 0.99 & $-100 \% *$ \\
UniCredit & Spain & 0.78 & $-100 \% *$ \\
Banco Santander & & & \\
Rest of Europe: & Switzerland & 4.92 & $41.9 \%$ \\
Credit Suisse & UK & 4.37 & $-14.8 \%$ \\
Barclays Bank & UK & 3.97 & $-62.3 \%$ \\
Lloyds TSB Bank & Switzerland & 3.32 & $-49.4 \%$ \\
UBS & UK & 2.29 & $-61.7 \%$ \\
RBS & UK & 1.49 & n.a. \\
HSBC & & & \\
\hline \hline
\end{tabular}

Notes. This table reports money-market-fund (MMF) reliance for the 11 Eurozone banks that were among the top fifty lenders in the U.S. syndicated loan market between 2005 and 2007. We also include MMF data for those European banks outside the Eurozone that were among the top 50 lenders in the U.S. MMF reliance equals MMF holdings as of April 2011 divided by (Deposits + Short Term Debt) as of the end of 2010. Change in MMF reliance is compiled from multiple Fitch Ratings reports on U.S. money-market fund exposure to European banks. Fitch reports highlight banks with the largest use of MMFs by country. Some of the banks or even entire countries are dropped from the coverage when their use of MMFs becomes very small; those cases are indicated by an asterisk. 
TABLE IV

SHARE OF DOLLAR LENDING

\begin{tabular}{|c|c|c|c|c|c|c|c|c|}
\hline \multirow{4}{*}{$\begin{array}{l}\text { Banks: } \\
\text { Market: }\end{array}$} & \multicolumn{4}{|c|}{ Eurozone banks } & \multirow{2}{*}{\multicolumn{4}{|c|}{$\begin{array}{c}\text { Eurozone and U.S. banks } \\
\text { Europe and U.S. }\end{array}$}} \\
\hline & \multicolumn{2}{|c|}{ Europe and U.S } & \multicolumn{2}{|c|}{ Europe } & & & & \\
\hline & Loan volume & Number of loans & Loan volume & Number of loans & \multicolumn{2}{|c|}{ Loan volume } & \multicolumn{2}{|c|}{ Number of loans } \\
\hline & (1) & $(2)$ & (3) & (4) & (5) & (6) & (7) & (8) \\
\hline SHOCK (05/2011-06/2012) & $\begin{array}{c}-0.0348 * \\
{[0.020]}\end{array}$ & $\begin{array}{c}-0.0328 * * \\
{[0.013]}\end{array}$ & $\begin{array}{c}-0.0365 * \\
{[0.020]}\end{array}$ & $\begin{array}{l}-0.0342 * * * \\
{[0.013]}\end{array}$ & $\begin{array}{l}0.0053 \\
{[0.014]}\end{array}$ & -- & $\begin{array}{c}-0.0007 \\
{[0.002]}\end{array}$ & -- \\
\hline EUROBANK*SHOCK & -- & -- & -- & -- & $\begin{array}{c}-0.0398 * \\
{[0.020]}\end{array}$ & $\begin{array}{c}-0.0398 * \\
{[0.021]}\end{array}$ & $\begin{array}{c}-0.0313 * * \\
{[0.013]}\end{array}$ & $\begin{array}{c}-0.0313^{* *} \\
{[0.014]}\end{array}$ \\
\hline USD/Euro spot exchange rate & $\begin{array}{l}0.1182 \\
{[0.073]}\end{array}$ & $\begin{array}{l}0.1535^{* * *} \\
{[0.050]}\end{array}$ & $\begin{array}{l}0.1282 * \\
{[0.075]}\end{array}$ & $\begin{array}{l}0.1577^{* * *} \\
{[0.050]}\end{array}$ & $\begin{array}{l}0.0916^{*} \\
{[0.054]}\end{array}$ & -- & $\begin{array}{l}0.0996 * * * \\
{[0.032]}\end{array}$ & -- \\
\hline \multicolumn{9}{|l|}{ Fixed effects: } \\
\hline $\operatorname{Bank}\left(D_{i}\right)$ & Yes & Yes & Yes & Yes & Yes & Yes & Yes & Yes \\
\hline Month $\left(D_{t}\right)$ & -- & -- & -- & -- & -- & Yes & -- & Yes \\
\hline Obs. & 1,188 & 1,188 & 1,188 & 1,188 & 1,836 & 1,836 & 1,836 & 1,836 \\
\hline Clusters $\left(D_{t}\right)$ & 108 & 108 & 108 & 108 & 108 & 108 & 108 & 108 \\
\hline Adj. $R$-squared & 0.09 & 0.14 & 0.09 & 0.14 & 0.83 & 0.86 & 0.91 & 0.91 \\
\hline
\end{tabular}

Notes. The dependent variable is the fraction of loans originated by bank $i$ in month $t$ that is denominated in U.S. dollars ( $\left.S_{i t}\right)$. The sample includes all loans originated between 2005 and 2013 that are denominated in U.S. dollars or euros; all other currencies are excluded from the sample. In specifications (1) through (4) we look at Eurozone banks only, specifications (5) through (8) look at U.S. and Eurozone banks. Specifications (3) and (4) look at lending in the European market only; the rest of the specifications look at lending in U.S. and European markets. Specifications (1) through (4) correspond to:

$$
S_{i t}=D_{i}+\beta S H O C K+F X_{t}
$$

$D_{i}$ is an originating bank fixed effect and SHOCK is a dummy variable equal to 1 for the May 2011-June 2012 period and 0 otherwise. Specification (8) includes month fixed effects and corresponds to:

$$
S_{i t}=D_{i}+D_{t}+\beta E U R O B A N K_{i} * S H O C K+F X_{t}
$$

EUROBANK is a dummy variable equal to 1 if bank's headquarters are located in the Eurozone and 0 otherwise. Standard errors, reported in brackets, are clustered by month. The average of the dependent variable $\left(S_{i t}\right)$ is $16.5 \%$ for Eurozone banks and $89.3 \%$ for U.S. banks, thus the high $R$-squared in specifications (5) through (8) is due to increased explanatory power of bank fixed effects. Significance at the $1 \%, 5 \%$, and $10 \%$ levels is indicated by ***, **, and *, respectively. 


\section{TABLE V \\ CHOICE OF LENDER FOR DOLLAR-DENOMINATED LOANS}

\begin{tabular}{|c|c|c|c|c|c|}
\hline \multirow{3}{*}{$\begin{array}{c}\text { Market: } \\
\text { Loan currency: }\end{array}$} & \multicolumn{5}{|c|}{ Europe and U.S. } \\
\hline & \multicolumn{2}{|c|}{ U.S. dollar } & \multicolumn{3}{|c|}{ U.S. dollar and euro } \\
\hline & $(1)$ & $(2)$ & $(3)$ & (4) & $(5)$ \\
\hline SHOCK & $\begin{array}{c}-0.0105^{* *} \\
{[0.005]}\end{array}$ & $\begin{array}{l}-0.0119 * * \\
{[0.005]}\end{array}$ & $\begin{array}{l}0.0662 * * * \\
{[0.019]}\end{array}$ & -- & -- \\
\hline DOLLAR LOAN*SHOCK & -- & -- & $\begin{array}{l}-0.0763 * * * \\
{[0.019]}\end{array}$ & $\begin{array}{l}-0.0758 * * * \\
{[0.019]}\end{array}$ & $\begin{array}{l}-0.0762 * * * \\
{[0.023]}\end{array}$ \\
\hline DOLLAR LOAN & -- & -- & $\begin{array}{l}-0.0673 * * * \\
{[0.0219]}\end{array}$ & $\begin{array}{l}-0.0664 * * * \\
{[0.022]}\end{array}$ & $\begin{array}{l}-0.5431^{* * *} \\
{[0.007]}\end{array}$ \\
\hline Ln(Loan amount) & -- & $\begin{array}{l}0.0041^{* *} \\
{[0.002]}\end{array}$ & $\begin{array}{c}-0.0017 \\
{[0.002]}\end{array}$ & $\begin{array}{c}-0.0021 \\
{[0.002]}\end{array}$ & $\begin{array}{l}-0.0011 \\
{[0.001]}\end{array}$ \\
\hline Fixed effects: & & & & & \\
\hline Borrower $\left(D_{j}\right)$ & Yes & Yes & Yes & Yes & -- \\
\hline Month $\left(D_{t}\right)$ & -- & -- & -- & Yes & Yes \\
\hline Industry $\left(D_{S I C}\right)$ & -- & -- & -- & -- & Yes \\
\hline Obs. & 32,309 & 32,303 & 37,236 & 37,236 & 36,340 \\
\hline Clusters $\left(D_{t}\right)$ & 168 & 168 & 168 & 168 & 168 \\
\hline Adj. $R$-squared & 0.73 & 0.73 & 0.83 & 0.83 & 0.42 \\
\hline
\end{tabular}

Notes. Each observation used for the analysis reported in this table is a separate loan. The dependent variable is EUROBANK SHARE, a variable between 0 and 1 equal to fraction of lead banks on the loan headquartered in the Eurozone. Specifications (1) and (2) include only U.S. dollars denominated loans and correspond to:

$$
\text { EUROBANK SHARE } E_{j t}=D_{j}+\beta S H O C K+X_{j},
$$

The rest of specifications include U.S. dollar denominated and euro loans. In particular, specification (4) corresponds to:

$$
\text { EUROBANK SHARE } E_{j t}=D_{j}+D_{t}+\text { DOLLARLOAN } j t+\beta D O L L A R L O A N_{j t} * S H O C K+X_{j}
$$

where the $D_{j}$ are borrower fixed effects. That is, the coefficient of interest, $\beta$, is identified off repeated loans to the same borrower. The $D_{t}$ are month fixed effects. DOLLAR LOAN is a dummy for the loan being denominated in U.S. dollars. SHOCK is a dummy variable equal to 1 for May, 2011-June, 2012 period and 0 otherwise. $X_{j}$ is loan size; we include it as a control because the number of lead lenders depends on loan size. We use loans issued over 2000-2013 period to assure that there are enough repeated loans in our sample. In specification (5), we replace borrower fixed effects with 2-digit Standard Industrial Classification (SIC) code fixed effects. Standard errors, reported in brackets, are clustered by month. Significance at the $1 \%, 5 \%$, and $10 \%$ levels is indicated by $* * *, * *$, and *, respectively. 
TABLE VI

LIKELIHOOD OF OBTAINING A DOLLAR-DENOMINATED LOAN

\begin{tabular}{|c|c|c|c|c|}
\hline \multirow[t]{2}{*}{$\begin{array}{c}\text { Market: } \\
\text { Loan currency: }\end{array}$} & \multicolumn{4}{|c|}{$\begin{array}{c}\text { Europe and U.S. } \\
\text { U.S. dollar }\end{array}$} \\
\hline & $(1)$ & $(2)$ & (3) & $(4)$ \\
\hline PAST EUROBANK SHARE (last loan) & $\begin{array}{l}-0.0542 * * * \\
{[0.011]}\end{array}$ & $\begin{array}{l}-0.0418^{* * *} \\
{[0.012]}\end{array}$ & $\begin{array}{l}-0.0487^{* * *} \\
{[0.012]}\end{array}$ & -- \\
\hline PAST EUROBANK SHARE (5-yr avg) & -- & -- & -- & $\begin{array}{l}-0.0635^{* * *} \\
{[0.012]}\end{array}$ \\
\hline All-in-drawn spread & -- & -- & $\begin{array}{l}-0.0002^{* * *} \\
{[0.000]}\end{array}$ & $\begin{array}{l}-0.0002^{* * *} \\
{[0.000]}\end{array}$ \\
\hline No spread information & -- & -- & $\begin{array}{l}-0.0601^{* * *} \\
{[0.011]}\end{array}$ & $\begin{array}{l}-0.0592 * * * \\
{[0.011]}\end{array}$ \\
\hline Ln(Loan amount) & -- & -- & $\begin{array}{l}0.0295 * * * \\
{[0.003]}\end{array}$ & $\begin{array}{l}0.0297 * * * \\
{[0.003]}\end{array}$ \\
\hline Maturity & -- & -- & $\begin{array}{l}0.0038 * * \\
{[0.002]}\end{array}$ & $\begin{array}{l}0.0038^{* *} \\
{[0.002]}\end{array}$ \\
\hline Revolving line & -- & -- & $\begin{array}{l}0.0310^{* * *} \\
{[0.008]}\end{array}$ & $\begin{array}{l}0.0303^{* * *} \\
{[0.008]}\end{array}$ \\
\hline Fixed effects: & & & & \\
\hline $\begin{array}{l}\text { Industry }\left(D_{S I C}\right) \\
\text { Year of last loan origination }\end{array}$ & $\begin{array}{l}-- \\
--\end{array}$ & $\begin{array}{l}\text { Yes } \\
\text { Yes }\end{array}$ & $\begin{array}{l}\text { Yes } \\
\text { Yes }\end{array}$ & $\begin{array}{l}\text { Yes } \\
\text { Yes }\end{array}$ \\
\hline Observations & 10,190 & 9,444 & 9,441 & 9,441 \\
\hline$R$-squared & 0.00 & 0.21 & 0.23 & 0.23 \\
\hline
\end{tabular}

Notes. The dependent variable is an indicator for whether the borrower received a U.S. dollar-denominated loan between May, 2011 and June, 2012 (the "shock period"). Due to the presence of fixed effects, the model is estimated as a linear probability model. The sample includes all borrowers that received a dollar-denominated loan before the shock period. With the exception of borrower 2-digit Standard Industrial Classification (SIC) code fixed effects, control variables correspond to the last pre-shock dollar-denominated loan. The explanatory variable of interest in specifications (1)-(3) is PAST EUROBANK SHARE, a variable between 0 and 1 equal to fraction of lead banks on the last pre-shock loan headquartered in the Eurozone. In specification (4), we compute PAST EUROBANK SHARE as the average of the last pre-shock loan and any other loans issued in the preceding 5 years. Robust standard errors are reported in brackets. Significance at the $1 \%, 5 \%$, and $10 \%$ levels is indicated by $* * *, * *$, and *, respectively. 


\section{TABLE VII}

\section{THE EFFECT OF LENDER TYPE ON LOAN SPREADS}

\begin{tabular}{llll}
\hline \multicolumn{1}{c}{$\begin{array}{c}\text { Market: } \\
\text { Loan currency: }\end{array}$} & \multicolumn{3}{c}{ Europe and U.S. } \\
\cline { 2 - 4 } & \multicolumn{3}{c}{$(1)$ U.S. dollar } \\
\hline PAST EUROBANK SHARE & $34.577^{*}$ & $45.09^{* * *}$ & $39.073^{* *}$ \\
All-in-drawn spread & {$[18.085]$} & {$[16.059]$} & {$[15.704]$} \\
& -- & -- & $-0.439^{* * *}$ \\
Ln(Loan amount) & & & {$[0.048]$} \\
& -- & -- & $-18.219^{* * *}$ \\
Maturity & & & {$[3.169]$} \\
& -- & -- & $13.851^{* * *}$ \\
Loan type & & & {$[2.531]$} \\
& -- & -- & $-74.047^{* * *}$ \\
Fixed effects: & & & {$[9.104]$} \\
Industry $\left(D_{\text {SIC }}\right)$ & & & \\
Year of last loan origination & -- & Yes & Yes \\
Observations & 3,816 & 3,816 & 3,816 \\
Clusters $\left(D_{j}\right)$ & 1,413 & 1,413 & 1,413 \\
$R$-squared & 0.08 & 0.33 & 0.45 \\
\hline \hline
\end{tabular}

Notes. The dependent variable is the increase in interest spread charged over LIBOR for U.S. dollars-denominated loans issued between May, 2011 and June, 2012 (the "shock period") as compared to the spread on the last dollar loan received by the same borrower before the shock. The explanatory variable of interest is PAST EUROBANK SHARE, a variable between 0 and 1 equal to fraction of lead banks on the last pre-shock loan headquartered in the Eurozone. The last two specifications also control for the year of origination of the last pre-shock loan. Spread, loan amount, and maturity reflect characteristics of the last loan issued before the shock period. The spread is measured at the loan facility or tranche level. The interest spread on the shock facilities are matched to the last pre-shock facility of the same type. Loans in a matched pair must be revolving lines, bank tranches, or institutional tranches. We exclude second-lien facilities. Standard errors are clustered by borrower. Significance at the $1 \%, 5 \%$, and $10 \%$ levels is indicated by $* * *, * *$, and *, respectively. 


\section{TABLE VIII \\ The EFFECT OF MONEY-Fund RELIANCE}

\begin{tabular}{|c|c|c|}
\hline \multirow[t]{3}{*}{ Market: } & \multicolumn{2}{|c|}{ Europe and U.S. } \\
\hline & $\begin{array}{l}\text { Most MMF } \\
\text { exposed banks }\end{array}$ & $\begin{array}{l}\text { Least MMF } \\
\text { exposed banks }\end{array}$ \\
\hline & $(1)$ & $(2)$ \\
\hline \multirow[t]{2}{*}{ SHOCK } & $-0.0095 * *$ & -0.0024 \\
\hline & {$[0.004]$} & {$[0.002]$} \\
\hline \multirow[t]{2}{*}{ Ln(Loan amount) } & $0.0032 * *$ & 0.0009 \\
\hline & {$[0.001]$} & {$[0.001]$} \\
\hline \multicolumn{3}{|l|}{ Fixed effects: } \\
\hline Borrower $\left(D_{j}\right)$ & Yes & Yes \\
\hline Obs. & 32,303 & 32,303 \\
\hline Clusters $\left(D_{t}\right)$ & 168 & 168 \\
\hline Adj. $R$-squared & 0.71 & 0.68 \\
\hline $\mathrm{H}_{0}: \beta_{\text {SHOCK}}$, most $\mathrm{M}$ & $\begin{array}{l}\text { lks }=\beta_{\text {SHOCK }}, \text { lec } \\
\text { tic }=6.20^{* *}\end{array}$ & exposed banks \\
\hline
\end{tabular}

Notes. The specifications reported here are analogous to Table V, column (2), the difference is the dependent variable. In specification (1), the dependent variable is the fraction of lead banks on the loan that are headquartered in the Eurozone and, as of April 2011, had over 4\% of their short-term funding coming from U.S. MMFs. In specification (2), the dependent variable is the fraction of lead banks on the loan that are headquartered in the Eurozone and, as of April 2011, had less than 4\% of their short term-funding coming from U.S. MMFs. As before, SHOCK is a dummy variable equal to 1 for May, 2011-June, 2012 period and 0 otherwise. We use loans issued over 2000-2013 period to assure that there are enough repeated loans in our sample. We control for loan size because the number of lead lenders depends on loan size. Standard errors, reported in brackets, are clustered by month. Significance at the $1 \%$, $5 \%$, and 10 $\%$ levels is indicated by $* * *, * *$, and *, respectively. 